\title{
Türkiye'de Bilgi ve Belge Yönetimi Müfredatlarında Okutulan Bilgisayar Programlarına ve Programlama Dillerine Yönelik Dersler*
}

\section{Courses on Computer Programs and Programming Languages Taught in Information and Records Management Curriculum in Turkey}

\author{
Ayşe Bayraktar ${ }^{1}$
}

* Bu çalışmanın bir bölümü 9 Kasım 2021 tarihinde gerçekleştirilen "XV. Arşivcilik Günü: Türk Arşivciliğinin Güncel Sorunları” adı Sempozyumda sözlü bildiri olarak sunulmustur.

'Ars. Gör., Osmaniye Korkut Ata Üniversitesi, Kadirli Sosyal ve Beşerî Bilimler Fakültesi, Bilgi ve Belge Yönetimi Bölümü, Osmaniye, Türkiye; Doktora Öğrencisi, İstanbul Üniversitesi,

Sosyal Bilimler Enstitüsü, İstanbul, Türkiye

ORCID: A.B. 0000-0002-9871-3599

Sorumlu yazar/Corresponding author: Ayșe Bayraktar,

Osmaniye Korkut Ata Üniversitesi, Kadirli Sosya ve Beşerî Bilimler Fakültesi, Bilgi ve Belge Yönetimi Bölümü, Osmaniye, Türkiye; Doktora Öğrencisi, İstanbul Üniversitesi Sosyal Bilimler Enstitüsü, İstanbul, Türkiye E-posta: aysebayraktar@osmaniye.edu.tr

Başvuru/Submitted: 03.12 .2021

Revizyon Talebi/Revision Requested: 09.12.2021 Son Revizyon/Last Revision Received: 11.12.2021 Kabul/Accepted: 13.12 .2021

Online Yayın/Published Online: 15.12.202

Attf/Citation: Bayraktar, A. (2021). Türkiye'de bilgi ve belge yönetimi müfredatlarında okutulan bilgisayar programlarına ve programlama dillerine yönelik dersler. Bilgi ve Belge Araştırmalart Dergisi, 16, 103-131

http://doi.org/10.26650/bba.2021.16.103218
ÖZ

Günümüzde artan ihtiyaçlar ve gelișen teknoloji ile doğru orantılı olarak bilgi teknolojilerinin kullanım oranlarının artığı bilinmektedir. Öğrencilerin eğitim-öğretim hayatlarında internet, teknoloji, erişim ve bilgisayar kavramı giderek daha fazla yer almaktadır. Bu durum birçok merakı beraberinde getirdiği gibi bilgisayar programlarına ve bilgisayar programlama dillerine olan ilginin ve ihtiyacın artmasını da sağlamıştır. Çalışma kapsamında Türkiye'de günümüzde eğitim-öğretim faaliyetlerini fiilen sürdürmekte olan bilgi ve belge yönetimi bölümlerinin müfredatında yer alan bilgisayar programlarına ve programlama dillerine yönelik dersler incelenmiştir. Ders adlarına ve içeriklerine lisans düzeyinde bilgi ve belge yönetimi bölümlerinin web sayfalarından erişilmiştir. Bu bağlamda ilk olarak bölümlerde lisans düzeyinde verilen derslerin toplam ders sayı ve oranları incelenmiş̧ir. Sonrasında ise bilgisayar programlarına ve programlama dillerine yönelik ders sayı ve oranları, bu sayı ve oranların zorunlu ya da seçmeli durumları ve içerikleri değerlendirilmiştir. Çalışmada nitel araştırma yöntemi ve durum çalıșmasından yararlanılmıștır Çalışmanın verileri ise doküman analizi yöntemiyle değerlendirilmiştir.

Anahtar kelimeler: Bilgi ve belge yönetimi, müfredat, bilgisayar programları, programlama dilleri

\section{ABSTRACT}

It is known that the usage rates of information technology increase proportionally to the increasing needs and developing technology. The concepts of the internet, technology, access, and computer are now commonplace in education. This situation led to increased curiosity, increasing the interest and need for computer programs and computer programming languages. Within the scope of the study, the courses for computer programs and programming languages in the curriculum of information and records management departments, which are currently continuing their educational activities in Turkey, were examined. Course titles and contents were obtained from the web pages of the bachelor-level information and records management departments. In this context, first, the total number of courses and course rates at the bachelor's level were examined. Later, an attempt was made to evaluate the number and the rates of computer programming language courses, the compulsory or the elective options, and rates and their contents. In this study, the data were obtained by using the qualitative research method and case study. The data were evaluated using the document analysis method.

Keywords: Information and records management, curriculum, computer programs, programming languages 


\section{EXTENDED ABSTRACT}

University institutions trying to fulfill age and department requirements develop their course curriculums in line with the developments in the use of information, communication, and technology. Earlier, it was thought that the computer program or programming language concepts were used only by departments within engineering faculties or vocational schools. Currently, this situation has changed. Computer programs or programming languages are used by many departments. It is predicted that the use of programming languages, which are a part of both the academic studies of the department faculty members and of the department courses, will become more widespread in the coming years.

Computer programming allows students to use more than one skill at the same time. To acquire these skills, they need to take the necessary programming education and training. These training can be provided to them as compulsory/elective courses or courses at various institutions or levels. First, the basic requirements such as attitude toward programming, interest in information technologies, computer literacy skills, and the working level with the chosen programming language are tested. Meeting these requirements helps students perform well in programming. Again, problem-solving skills in many areas can help students in creating algorithms independently of the programming language used, software development, and logical and analytical thinking. Electronic devices differ in terms of usage areas and purposes. To serve these areas and purposes, there are various programming languages. The language of the programmed devices consists of words and symbols customized for these purposes. The devices must be programmed using commands according to the language used. The resulting product is called a program.

By graduating from the information and records management department in courses related to computer programs and programming languages:

- Students can apply their acquired knowledge through the courses they have taken, to write basic algorithms and programs for making any necessary changes in the existing software design. The skills they will develop in the information centers and services will be helpful in their professional life.

- Students can analyze text and data structures on the web in the field of information and records management using a web mining approach.

- Students gain the skills to create dynamic websites on the web. This way, they become a part of the information cycle process in the online environment.

- Students learn to visualize information and present large-scale information content through tables and graphs. 
- Students learn about data types. They know that data of the institution they work for must be defined initially to be accessible later.

- Students gain theoretical and practical knowledge about information technologies in library and archive institutions.

- Students learn the methods and techniques of the electronic document management and archiving system. They gain skills in designing, establishing, and executing an electronic document management system for institutions and organizations.

- Students understand the basic criterion for creating and selecting an automation program for information centers.

Within the scope of the study, the courses for computer programs and programming languages in the curriculum of information and records management departments, which are currently continuing their educational activities in Turkey, were examined. Course titles and contents were obtained from the web pages of the bachelor-level information and records management departments. First, the total number of courses and course rates given at the bachelor's level were examined. Thereafter, an attempt was made to evaluate the number and the rates of courses for computer programs and programming languages, the compulsory or the elective situations of these numbers, and rates and their contents. In this study, the data were obtained by using the qualitative research method and case study. The data were evaluated using the document analysis method. 


\section{GíRIŞ}

Bilgisayar programlama, öğrenciler için aynı anda birden fazla becerinin kullanılmasına olanak veren üretim süreci anlamına gelmektedir. Bu becerilerin kazanılması için, kişisel merak yoluyla keşfetmenin yanı sıra programlama becerilerinin eğitim-öğretim yoluyla kazanılması önemlidir. Bu eğitimler farklı kurumlarda ya da kademelerde zorunlu/seçmeli dersler ya da kurslar halinde verilebilmektedir. Eğitimlerde başarılı olunabilmesi için temel faktörlerin başında öğrencilerin; programlamaya dair tutumları, bilişim teknolojilerine merakı, bilgisayar okuryazarlık becerileri ve seçilmiş olan programlama dili ile çalışılabilir olma düzeyleri gelmektedir. Bu faktörler öğrencilerin programlama alanındaki beceri seviyelerini olumlu yönde etkilemektedir. Yine bu faktörler öğrenciye, kullanılan programlama dilinden bağımsız bir şekilde algoritma oluşturma, yazılım geliştirme, mantıksal ve analitik düşünebilme gibi birçok alanda problem çözmeye yönelik beceriler kazandırmaktadır (Ersoy, Madran ve Gülbahar, 2011, s. 785). Bilgisayar programlama kurslarının özellikle yeni başlayanlar için oldukça zorlayıcı olduğu düşünülmektedir. Bunun nedeni programlamanın sürekli gelişen bir konu olmasidır (Zhao, Chis, Muntean, Muntean, 2018).

Elektronik cihazlar, kullanım alanları ve amaçları açısından farklılık göstermektedir. Bu alan ve amaçlara hizmet edebilmeleri için komutlanarak programlanmaları gerekmektedir. Programlanan cihazların dili, bu amaçlar doğrultusunda özelleştirilmiş kelime ve sembollerden oluşmaktadır. Oluşturulan komutlar ile bilgisayarların belirli işler yapmasını sağlayan programlar, diğer bir ifadeyle yazılımlar ortaya çıkmaktadır. Birbirinden farklı birçok programlama dili bulunmaktadır. Her bir programlama dili kendine özgü kural ve komutlarla çalışmaktadır. Özelleştirilmiş komutların yazılması, kodlama ya da programlama olarak adlandırılırken ortaya çıkan ürün ise program olarak nitelendirilmektedir (Ersoy, Madran ve Gülbahar, 2011, s. 786).

Programlama kodu, programlamayı öğrenmede çok önemli bir rol oynamaktadır. Programı anlama; kodu okuma, anlama ve izleme ile ilgiliyken program oluşturma; kodu yazma ve oluşturma ile ilgilidir (Hosseini, Akhuseyinoglu, Brusilovsky, Malmi, Pollari-Malmi, Schunn, ve Sirkiä, 2020, s. 299-300).

Çalışma kapsamında Türkiye'de hâlihazırda eğitim-öğretim faaliyetlerini sürdürmekte olan Bilgi ve Belge Yönetimi (BBY) Bölümlerinde bilgisayar programlarına ve programlama dillerine yönelik lisans düzeyinde yürütülen dersler incelenmiştir. Mevcut BBY Bölümlerinin sayısal durumuna Yükseköğretim Program Atlası (YÖK Atlas) (2021) üzerinden ulaşılmıştır. Bilgisayar programlarına ve programlama dillerine yönelik lisans düzeyinde okutulan derslerin adlarına ve içeriklerine ise bilgi ve belge yönetimi bölümlerinin resmî web sayfalarından erişilmiştir. Bu bağlamda ilk olarak bölümlerde lisans düzeyinde verilen derslerin toplam ders sayı ve oranları incelenmiştir. Sonrasında ise bilgisayar programlarına ve programlama dillerine yönelik ders sayı ve oranları, bu sayı ve oranların zorunlu ya da seçmeli durumları ve içerikleri 
değerlendirilmiştir. Ders içeriklerinde doğrudan bilgisayar programlarına ve programlama dilleri ile ilgili konuların ya da BBY bölümlerinin müfredatında ders konu başlıkları arasında (İstatistik, Bilgi Erişim ve Yayıncılık derslerinde olduğu gibi) bilgisayar programları ve programlama dilleri konularının kısmen işlendiği dersler çalışmanın kapsamına dâhil edilmiştir. Buna karşın mesleki bilgi ve beceri ile doğrudan alakalı görülmeyen "Türk Dili”, "Atatürk İlkeleri ve İnkılâp Tarihi”, "Yabancı Dil”, "Güzel Sanatlar” ve "Kariyer Planlaması" olarak bilinen ortak servis dersleri hem kapsam dışında bırakılmış hem de toplam ders sayılarına ve ders kredi oranlarına dâhil edilmemiştir. Çalışmada nitel araştırma yöntemi ve durum çalışmasından yararlanılmış olup, veriler doküman analizi yöntemiyle değerlendirilmiştir.

\section{Türkiye'de Bilgi ve Belge Yönetimi Bölümlerinin Kısa Tarihçeleri}

Türkiye'de bilgi ve belge yönetimi (arşivcilik, bilgi yönetimi ve kütüphanecilik) eğitim tarihi “1923-1952, 1953-1987, 1988-2001, 2002 ve sonrası" olarak dört dönemde ele alınmaktadır (Çakın, 2005, s. 8; Subaşığlu, 2014, s. 81; Yılmaz, 2018, s. 45).

\subsection{3-1952 Arası Dönem}

Cumhuriyetin ilanı sonrasında Türkiye'de kütüphanecilik alanında birçok önemli gelişme yaşanmıştır. "3 Mart 1924 tarihinde Tevhid-i Tedrisat Kanunu çıkarılması ile vakıflara bağlı olan kütüphane ve kitapların Maarif Vekâlet'ine devredilmesine karar verilmiştir” (Subaşığlu, 2014, s. 82). İlk çalışmalar H. Fehmi Edhem Karatay'ın Fransa'ya ve daha sonra Adnan Ötüken'in ise Almanya'ya gönderilmesi ile başlamıştır. Bu öğrenciler yurda döndükleri zaman kütüphanecilik alanında birçok ilke imza atmışlardır. Bu dönemde kütüphanecilik kursları açılmış ve Türkiye'de kütüphaneci yetiştirmenin önemine dair raporlar hazırlanmıştır. 1941 yılında, İstanbul Üniversitesi Rektörlüğü öncülüğünde kütüphanelere yeterli sayıda ve yetkin kütüphaneciler yetiştirmeyi amaçlayan bir kanun tasarısı hazırlanmıştır. Adnan Ötüken'in girişimiyle 1942-1952 yılları arasında Türkiye'de kısa süreli kursların yanı sıra yine kurs düzeyinde olmak üzere, "ilk devamlı ve düzenli kütüphanecilik eğitimi” Ankara Üniversitesi çatısı altında başlamıştır. Bu kurslarla birlikte kütüphanecilik eğitimi, ilk kez üniversite düzeyinde ele alınmıştır. 1952 yılında kütüphanecilik derslerinin Ankara Üniversitesi Dil ve Tarih-Coğrafya Fakültesi (DTCF), “Türk Dili ve Edebiyatı Kürsüsü” bünyesinde "seçmeli” bir ders olarak okutulmasına yönelik senato kararı alınmıştır (Subaşığlu ve Tamdoğan, 2014, s. 584-587; Y1lmaz, 2018, s. 45-46).

\subsection{3-1987 Arası Dönem}

Kütüphanecilik derslerinin “Türk Dili ve Edebiyatı Kürsüsünde” seçmeli ders olarak kabul edilmesi ile "Kütüphanecilik Enstitüsü”nün temelleri atılmıştır (Subaşığlu ve Tamdoğan, 2014, s. 590). 1954-1955 akademik dönemde ilk öğrenciler eğitim-öğretim hayatına başlamıştır (Çakın, 2005, s. 11; Subaşığlu, 2014, s. 83-84). 1960 yılında ise Kütüphanecilik Enstitüsü, 
Üniversitelerarası Kurul kararıyla “kürsü1”ye dönüştürülmüştür. Ayrıca 1960 yılında, Türkiye’de ilk defa lise seviyesinde "kütüphanecilik dersi" verilmiştir (Subaşığlu ve Tamdoğan, 2014, s. 593). 1964 yılında "Kütüphanecilik Bölümü” adını alan bu kürsü, 1970 yılı itibariyle programında bilgi bilim ile ilgili derslere yer vermiştir. Bölümde lisansüstü araştırmalar için çalışmalar 1971 yılında lisans mezunlarının talebi doğrultusunda başlamıştır. 1974-1975 akademik yılında ise bölümde bağımsız lisansüstü eğitim başlamıştır (Subaşığlu ve Tamdoğan, 2014, s. 597). 1989-1990 akademik y1lında "Arşivcilik" ve "Dokümantasyon-Enformasyon" anabilim dalları oluşturulmuştur. Böylece "Kütüphanecilik" anabilim dalı ile bölümde toplamda üç anabilim dalı var olmuştur (Genel Bilgiler, t.y.).

İstanbul Üniversitesi BBY Bölümü, “Kütüphanecilik Bölümü” adıyla Edebiyat Fakültesi bünyesinde 1963 yılında kurulmuştur. 1964-1965 akademik yılında öğretime başlayan bölüm, Ankara Üniversitesi DTCF Kütüphanecilik Bölümünden sonra Türkiye'de açılan ikinci kütüphanecilik bölümüdür. 1983 yılında yüksek lisans, 1984 yılında ise doktora programları açılmıştır. 1990 yılında "Kütüphanecilik”, “Dokümantasyon ve Enformasyon” olmak üzere diploma verme hakkına sahip iki anabilim dalı açılmıştır. 1995 yılı itibariyle ise Kütüphanecilik Anabilim Dalı'nda, ikinci öğretim programı açılmıştır. Arşivcilik Bölümü, YÖK 2002 kararına uygun olarak 2002-2003 yılında 'Bilgi ve Belge Yönetimi Bölümü' kapsamına alınmıştır (Bölümün Tarihçesi, 2021). Günümüzde bölüm, “Arşivcilik Anabilim Dalı” ile "Bilgi Yönetimi ve Teknolojisi Anabilim Dalı” olmak üzere iki anabilim dalına sahiptir” (Anabilim Dalları, 2021).

1972'de “Kütüphanecilik ve Dokümantasyon Enstitüsü” adıyla kurulan Hacettepe Üniversitesi BBY Bölümü, 1974’te bölüme öğrenci alımına başlamıştır. Programda bir yı1 yabancı dil hazırlık eğitimi verilirken, mesleki eğitim-öğretim süresi dört yıl olarak belirlenmiştir. Bölüm lisans programı “1978/1979”, “1983/1984” ve “1990/1991” akademik dönemlerinde değişime uğramıştır. 1993 yılı itibariyle bölüm, "Kütüphanecilik”, “Arşivcilik”, "Dokümantasyon ve Enformasyon" anabilim dallarına göre lisans eğitim-öğretim faaliyetlerini yürütmüştür. Bölümde lisansüstü eğitim ve öğretim programları da bulunmaktadır (Program Hakkında Genel Bilgi, t.y.).

\subsection{8-2001 Arası Dönem}

Kütüphanecilik bölümleri, "Kütüphanecilik", "Arşivcilik" ve "DokümantasyonEnformasyon" olmak üzere anabilim dallarına ayrılmış ve yapısal bir değişiklik geçirerek tekrar öğrenci alımlarına başlamıştır (Subaşığlu, 2014, s. 84). 1988-1992 yılları arasında kamu kurumları personeline arşiv hizmetlerini yürütebilmeleri için çeşitli hizmet içi eğitim programları ve seminerler düzenlenmiştir (Keskin, 2003, s. 173). Ayrıca İstanbul'da 1987 yılında iki ayrı arşivcilik bölümü kurulmuştur. Söz konusu bölümler İstanbul ve Marmara

1 Kürsü; “[...] Üniversitelerde aynı alandan ya da birbirine çok yakın alanlardaki bilim dallarından oluşan bir çalışma birimi [...]” olarak ifade edilmektedir (Türk Dil Kurumu, 2019). 
Üniversitelerinde öğretime başlamıştır (Keskin, 2003, s. 182-185; Keskin, 2011, s. 205). 1994 yılında, Atatürk Üniversitesi “Kütüphanecilik Bölümü” açılmıştır. 2008-2009 akademik yılında lisans (Yılmaz, 2010, s. 125-128), 2010-2011 öğretim yılında yüksek lisans programına öğrenci kabul edilmiştir (Odabaş, 2014, s. 131).

Ülkemizde bağımsız olarak arşivcilik eğitimi 1988-1989 eğitim-öğretim döneminde İstanbul ve Marmara Üniversitelerinde başlatılmıştır. Bu bölümlerde modern arşivler ve tarihi arşivler konularını öğretmeye yönelik dersler verilmiştir. Ayrıca öğrenciler arşivlerde çalışarak uygulama yapma fırsatı bulmuşlardır. Bu gelişmeler, sonraki yıllarda diğer kütüphanecilik bölümlerinin bünyelerinde arşivcilik anabilim dalı açılmasıyla devam etmiştir (Atılgan, 1995 s. 265-267; Rukanc1, 1998, s. 60-73; Keskin, 2003, s.182-185; Baydur ve Külcü, 2007, s. 27). Ankara Üniversitesi Arşivcilik Anabilim Dalı, 1988 yılında Kütüphanecilik Bölümüne bağlı olarak kurulmuşsa da 1995 yılında öğretim elemanı eksikliği gerekçesiyle öğrenci alımına son verilmiştir (Keskin, 2003, s.187). Hacettepe Üniversitesi Arşivcilik Anabilim Dalı ise 1994 yılında öğrenci alımına başlamıştır (Baydur ve Külcü, 2007, s. 27).

\subsection{2 ve Sonrası Dönem}

Türkiye'de 2002 yılına kadar anabilim dallarına ayrılan bölümlere bağlı anabilim dalları, "29 Ocak 2002 tarihli Yükseköğretim Kurulu (YÖK) Yürütme Kurulu toplantısında, 2547 sayılı Kanun’un 2880 sayılı Kanun değişik 7/d-2 ve 7/h maddeleri uyarınca, 2002-2003 öğretim yılı itibariyle kütüphanecilikle ve arşivcilikle ilgili bölüm adları "Bilgi ve Belge Yönetimi Bölümü” olarak değiştirilmiştir” (Çakın, 2012, s. 273). İstanbul Üniversitesi Arşivcilik Bölümü ise kapatılmış; kadrosu ismi değiştirilen aynı fakültenin kütüphanecilik bölümüne aktarılmıştır. Bölümlere öğrenci alımları sırasında aranan puan türü “sözel”den "eşit ağırlıklı"ya dönüştürülmüştür (Çakın, 2005, s. 20; Subaşığlu, 2014, s. 85; Yılmaz, 2018, s. 46). Ayrıca YÖK kararıyla Başkent Üniversitesi, İletişim Fakültesinde Bilgi ve Belge Yönetimi Bölümü kurulmuştur. Bölüm, öğrencilerini 2002-2003 akademik yılında almaya başlamıştır (Çakın, 2005, s. 19). Söz konusu bölümün eğitim-öğretim faaliyetleri kısa sürmüş ve 2006 tarihinde sonlanmıştır (Keskin, 2011 s. 207).

Ayrıca resmi olarak kurulmuş fakat eğitim-öğretim faaliyetlerini sürdürmeyen üniversiteler de olmuştur. Bunlar; Kıbrıs Yakın Doğu, Gümüşhane, Fatih Sultan Mehmet, Ardahan, Murat Hüdavendigar, Karabük Üniversiteleri BBY bölümleridir (Subaşığlu, 2014, s. 85; Yılmaz, 2018, s. 46).

Eğitim-öğretim faaliyetlerinde bulunan diğer BBY bölümleri hakkındaki genel bilgiler ise şu şekildedir: Kastamonu Üniversitesi BBY Bölümü, 2007 yılında Fen-Edebiyat Fakültesi içerisinde kurulmuştur. İlk elemanını 2010 yılında alan bölümde, "Arşivcilik", "Bilgi Yönetimi ve Teknolojisi”, “Kütüphanecilik” ve "Müessese Arşivleri” anabilim dalı bulunmaktadır 
(Bilgi ve Belge Yönetimi Genel Bilgiler, 2021; Ana Bilim Dalları, 2021). Çankırı Karatekin Üniversitesi BBY Bölümü, 2010 yılında kurulmuş olup 2013-2014 akademik yılında öğrenci alımına başlamıştır. Bölümde yüksek lisans ve doktora programları bulunmaktadır (Bölüm Tanıtımı, 2021). Ankara Yıldırım Beyazıt Üniversitesi BBY Bölümü, İnsan ve Toplum Bilimleri Fakültesi bünyesinde 2011 y1lında kurulmuştur. 2014'te bölüme öğrenci kabulü başlanan (Yılmaz, 2018, s. 48) bölümde "Bilgi Yönetimi” ve “Arşivcilik” olmak üzere iki ayrı anabilim dalı bulunmaktadır (Akademik Kadro, 2020). İstanbul Medeniyet Üniversitesi BBY Bölümü, 2011 yılında kurulmuştur. Bölüme öğrenci alımı 2016-2017 akademik yılında başlamıştır. Öğrencilere lisans ve yüksek lisans düzeyinde öğretim verilmektedir. Bölümde, 2019 yılı itibariyle "Kütüphanecilik" ve "Arşivcilik" olmak üzere iki anabilim dalı kurulmuştur (Tanıtım, 2021). İzmir Kâtip Çelebi Üniversitesi BBY Bölümü, 2012 yılında Sosyal ve Beşeri Bilimler Fakültesi içerisinde kurulmuştur. 2020-2021 akademik döneminde bölüme öğrenci alımı yapılmıştır (Bölümümüz Hakkında, 2021). Bölümde lisans ve yüksek lisans programları vardır. Osmaniye Korkut Ata Üniversitesi BBY Bölümü, 2016 yılında Kadirli Sosyal ve Beşeri Bilimler Fakültesinde kurulmuştur. Bölüm, ilk öğrencilerini 2017-2018 akademik yılında almıştır. Bölümde eğitim-öğretim faaliyetleri lisans düzeyinde verilmektedir (Tarihçe, t.y.a). Bartın Üniversitesi BBY Bölümü, 2018 yılında kurulmuş olup, 2020-2021 akademik yılında öğrenci alımına başlamıştır. Bölüm, "Bilgi Yönetimi ve Teknolojileri” ve “Arşiv” olmak üzere iki anabilim dalından oluşmaktadır (Tarihçe, t.y.b). İstanbul 29 Mayıs Üniversitesi BBY Bölümü, 2021 yılında Edebiyat Fakültesi bünyesinde kurulmuştur. Bölüme öğrenci kabulü, 2021-2022 akademik yılı itibariyle başlamıştır (Bilgi ve Belge Yönetimi Bölümü, 2021).

2021 yılı itibariyle YÖK Atlas üzerinden elde edilen verilere göre eğitim-öğretim faaliyetlerine aktif olarak devam eden bilgi ve belge yönetimi bölüm sayısı on üçtür.

Tablo 1: Türkiye’de Bilgi ve Belge Yönetimi Bölümleri (BBY)

\begin{tabular}{|l|l|l|c|c|c|}
\hline $\begin{array}{l}\text { Kuruluş } \\
\text { Tarihi }\end{array}$ & Kuruluş Yeri & Fakülte & Lisans & $\begin{array}{c}\text { Yüksek } \\
\text { Lisans }\end{array}$ & Doktora \\
\hline $\begin{array}{l}1954- \\
1955\end{array}$ & Ankara Üniversitesi & $\begin{array}{l}\text { Dil ve Tarih-Coğrafya } \\
\text { Fakültesi }\end{array}$ & $\checkmark$ & $\checkmark$ & $\checkmark$ \\
\hline 1963 & İstanbul Üniversitesi & Edebiyat Fakültesi & $\checkmark$ & $\checkmark$ & $\checkmark$ \\
\hline 1972 & Hacettepe Üniversitesi & Edebiyat Fakültesi & $\checkmark$ & $\checkmark$ & $\checkmark$ \\
\hline 1987 & Marmara Üniversitesi & Fen-Edebiyat Fakültesi & $\checkmark$ & $\checkmark$ & $\checkmark$ \\
\hline 1994 & Atatürk Üniversite & Edebiyat Fakültesi & $\checkmark$ & $\checkmark$ & X \\
\hline 2007 & Kastamonu Üniversitesi & Fen-Edebiyat Fakültesi & $\checkmark$ & X & X \\
\hline 2010 & Çankırı Karatekin Üniversitesi & Edebiyat Fakültesi & $\checkmark$ & $\checkmark$ & $\checkmark$ \\
\hline 2011 & $\begin{array}{l}\text { Ankara Yıldırım Beyazıt } \\
\text { Üniversitesi }\end{array}$ & $\begin{array}{l}\text { İnsan ve Toplum Bilimleri } \\
\text { Fakültesi }\end{array}$ & $\checkmark$ & X & X \\
\hline 2011 & İstanbul Medeniyet Üniversitesi & Edebiyat Fakültesi & $\checkmark$ & $\checkmark$ & X \\
\hline
\end{tabular}




\begin{tabular}{|l|l|l|c|c|c|}
\hline 2012 & İzmir Kâtip Çelebi Üniversitesi & $\begin{array}{l}\text { Sosyal ve Beşeri Bilimler } \\
\text { Fakültesi }\end{array}$ & $\checkmark$ & $\checkmark$ & X \\
\hline 2016 & $\begin{array}{l}\text { Osmaniye Korkut Ata } \\
\text { Üniversitesi }\end{array}$ & $\begin{array}{l}\text { Kadirli Sosyal ve Beşeri } \\
\text { Bilimler Fakültesi }\end{array}$ & $\checkmark$ & X & X \\
\hline 2018 & Bartın Üniversitesi & Edebiyat Fakültesi & $\checkmark$ & X & X \\
\hline $2021^{2}$ & İstanbul 29 Mayıs Üniversitesi & Edebiyat Fakültesi & $\checkmark$ & X & X \\
\hline
\end{tabular}

\section{Bilgisayar Programları ve Programlama Dilleri Derslerinin Öğretimde Yararları}

Bilgi ve Belge Yönetimi (BBY) bölümlerinde okuyan ya da mezun olan öğrencilerin, öğrenimleri sırasında aldıkları bilgisayar programları ve programlama dilleriyle alakalı derslerde elde ettikleri kazanımlarını maddeler halinde aşağıdaki gibi ifade etmek mümkündür:

- Öğrenciler, bilgisayar programları ve programlama dilleriyle alakalı almış oldukları dersler ve bu doğrultuda geliştirecekleri becerileri ile meslek hayatlarında çalışacakları bilgi merkezlerinde ve hizmetlerinde, kullanıcılar için geliştirilecek olan yazılımların tasarımı üzerinde gerekli değişikliklerin yapılması için temel düzeyde algoritma ve program yazabilme becerisi kazanmaktadır.

- Öğrenciler, bilgi ve belge yönetimi alanında webdeki metin ve veri yapıları üzerinde veri, web ve metin madenciliği yaklaşımıyla analizlerini yapabilir.

- Öğrenciler, web üzerinde dinamik web siteleri oluşturabilme becerilerini kazanırlar. Bu sayede çevrimiçi ortamdaki bilgi döngüsü sürecinin bir parçası olurlar.

- Öğrenciler, elde ettikleri bilgiyi görselleştirme, tablo ve grafikler aracilığıyla sunabilmeyi öğrenirler.

- Öğrenciler, veri türü hakkında bilgi sahibi olurlar. Çalıştıkları kurum verilerinin daha sonra erişilebilir olması için nasıl tanımlanması gerektiğini bilirler.

- Öğrenciler, kütüphane ve arşiv kurumlarındaki bilgi teknolojilerine ilişkin teorik ve pratik bilgiler kazanırlar.

- Öğrenciler, elektronik belge yönetimi ve arşivleme sisteminin yöntemlerini ve tekniklerini öğrenirler.

- Öğrenciler, bilgi merkezleri için otomasyon programı oluşturma ve seçiminde temel kriterlerin neler olduğunu anlarlar.

2 Kuruluş tarihi bilgisi 06.11.2021 tarihinde bölüm öğretim elemanı ile yapılan görüşme yoluyla elde edilmiştir. 


\section{Araştırmanın Amacı, Önemi ve Yöntemi}

\subsection{Araştırmanın Amacı ve Önemi}

Çalışmanın amacı; BBY bölümlerinin lisans düzeyinde toplam ders sayı ve oranlarını ortaya koymak, bilgisayar programlarına ve programlama dillerine yönelik ders sayı ve oranlarını tespit etmek, bu sayı ve oranların zorunlu ve seçmeli durumlarıla içeriklerini değerlendirmeye çalışmaktır. Bu amaç doğrultusunda aşağıda belirtilen sorulara cevaplar aranmıştır. Bunlar;

- BBY bölümlerinin lisans düzeyinde toplam, zorunlu ve seçmeli ders sayı ve oranlarının durumu nedir?

- Bölümlerde okutulan bilgisayar programlarına ve programlama dillerine yönelik derslerin toplam, zorunlu ve seçmeli ders sayı ve oranlarının durumu nedir?

- Bölümlerde okutulan bilgisayar programlarına ve programlama dillerine yönelik derslerin içerikleri nasıl ele alınmıştır?

- Bölümler bilgisayar programlarına ve programlama dillerine yönelik ders içerikleri bakımından hangi durumdadır?

$\mathrm{Bu}$ soruların cevapları bölümlerin bilgisayar programlarına ve programlama dillerine yönelik derslerinin müfredat içerisinde hangi oranda yer aldığını ortaya koyacaktır. Böylelikle bölümlerin ilgili ders yoğunlukları konusunda durum analizi yapılması mümkün olabilecektir.

\subsection{Araştırmanın Yöntemi}

Çalışma kapsamında günümüzde Türkiye'de YÖK Atlas (2021) üzerinde eğitim-öğretim faaliyetlerini sürdürmekte olan bilgi ve belge yönetimi bölümleri öncelikle sayıca ele alınmıştır. Lisans düzeyindeki ders adlarına ve içeriklerine ise BBY bölümlerinin web sayfalarından erişilmiştir. Bu bağlamda ilk olarak bütün bölümler tarafından lisans düzeyinde yürütülen toplam ders sayıları incelenmiştir. Sonrasında ise bilgisayar programları ve programlama dillerine yönelik dersler ve bu derslerin diğer derslere oranları, bu sayı ve oranların zorunlu ya da seçmeli durumları ve içerikleri değerlendirilmeye çalışılmıştır. Bilgisayar programları ve programlama dilleri ile ilgili konuların doğrudan ya da kısmen işlendiği dersler (İstatistik, Bilgi Erişim ve Yayıncılık) çalışmanın kapsamına dâhil edilmiş̧ir. Ortak servis dersleri olarak bilinen “Türk Dili”, "Atatürk İlkeleri ve İnkılâp Tarihi”, "Yabancı Dil”, "Güzel Sanatlar” ve "Kariyer Planlaması" dersleri ise bu çalışmada tamamen kapsam dışında bırakılmıştır.

$\mathrm{Bu}$ çalışmada veriler nitel araştırma yöntemi ve durum çalışmasından yararlanılarak elde edilmiş olup, veriler doküman analizi tekniğiyle değerlendirilmiştir. Yıldırım ve Şimşek (2018)'e göre “nitel araştırma; gözlem, görüşme ve doküman analizi gibi temel veri toplama 
yöntemlerinin kullanıldığı, algıların ve olayların doğal ortamda gerçekçi ve bütüncül bir biçimde ortaya konmasına yönelik nitel bir sürecin izlendiği araştırma" olarak tanımlanmaktadır.

\section{Bulgular}

\subsection{Bilgisayar Programlarına ve Programlama Dillerine Yönelik Dersler}

Çalışmanın bu bölümünde yukarıda tarihsel süreçlerinden kısaca bahsedilen on üç bölümün lisans ders müfredatlarında okutulan bilgisayar programları ve programlama dillerine yönelik dersleri ele alınmıştır. Bu bağlamda ders programlarında mevcut bulunan ders sayısı, zorunlu ve seçmeli statüleri incelenmiştir.

Tablo 2'de lisans programı toplam ders sayıları incelendiğinde, derslerin Ankara Yıldırım Beyazıt Üniversitesi BBY (52) ile Kastamonu Üniversitesi BBY (90) bölümleri arasında ders sayıları açısından geniş bir aralıkta dağılım gösterdiği görülmektedir. Üniversitelerin kuruluş yıllarına göre bakıldığında en son kurulan Bartın Üniversitesi BBY, İstanbul 29 Mayıs Üniversitesi BBY ve Osmaniye Korkut Ata Üniversitesi BBY bölümlerinin toplam ders sayılarının sırasıyla 53, 58 ve 80 olduğu görülmektedir. Bu durum ders sayıları bakımından eski tarihli kurulmuş bölümler ile yeni tarihli kurulan bölümler arasında farklılık olmadığını ortaya koymaktadır. Bölümlerin lisans programı toplam ders sayılarına bakıldığında 6 BBY bölümü toplam 75 ve üzerinde ders sayısına sahip iken kalan 7 bölümün ise 52-73 arasında ders sayısına sahip olduğu görülmektedir. Zorunlu ders sayısı, 46 ders ile en çok İstanbul 29 Mayıs Üniversitesi BBY bölümünde bulunurken 18 ders ile en az Hacettepe Üniversitesi BBY bölümünde bulunmaktadır. Seçmeli ders sayısına bakıldığında ise Çankırı Karatekin Üniversitesi BBY bölümü en çok derse (51) sahip bölüm iken Ankara Yıldırım Beyazıt Üniversitesi BBY bölümü en az ders sayısına (10) sahiptir.

Çalışma kapsamında ele alınan BBY bölümleri müfredatlarında lisans düzeyinde okutulan bilgisayar programları ve programlama dilleri ile ilgili dersler Tablo 2'de verilmiştir. Bu alanda en çok derse sahip bölümler İstanbul 29 Mayıs Üniversitesi BBY (16), Ankara Üniversitesi BBY (15) ve İzmir Kâtip Çelebi Üniversitesi BBY (15) bölümleridir. En az derse sahip olan bölümler ise Osmaniye Korkut Ata Üniversitesi BBY (7), İstanbul Üniversitesi BBY (8) ve Ankara Yıldırım Beyazıt Üniversitesi BBY (9) bölümleridir. BBY müfredatlarında lisans düzeyinde bilgisayar programları ve programlama dilleri derslerinin zorunlu ve seçmeli statüleri arasında (İstanbul 29 Mayıs Üniversitesi BBY bölümünü hariç) fark edilir düzeyde farklılıklar bulunmaktadır. Altı bölümde zorunlu statüsünde ders sayısı 5 ve 5 'in altındayken sadece üç bölümde 8 adet zorunlu ders sayısı bulunmaktadır. Bölümlerde bu konularda verilen dersler daha çok seçmeli statüsünde yer almaktadır. Bilgisayar programları ve programlama dilleri ile ilgili zorunlu ve seçmeli ders durumlarını değerlendirecek olursak, en fazla zorunlu ders (8) Kastamonu Üniversitesi BBY, Ankara Yıldırım Beyazıt Üniversitesi BBY (8) ve 
İstanbul 29 Mayıs Üniversitesi BBY (8) bölümlerine aittir. En az seçmeli ders ise (1) Ankara Yıldırım Beyazıt Üniversitesi BBY, (2) İstanbul Üniversitesi BBY ve (3) Osmaniye Korkut Ata Üniversitesi BBY bölümlerine aittir.

Bilgisayar programları ve programlama dilleri ile ilgili toplam ders oranlarına bakıldığında, konu ile ilgili en yoğun ders müfredatına İstanbul 29 Mayıs Üniversitesi BBY bölümünün $(\% 27,59)$ sahip olduğu görülmektedir. Onu, \%25,42 oranla İzmir Kâtip Çelebi Üniversitesi BBY bölümü takip etmektedir. Genel olarak bilgisayar programları ve programlama dilleri ile ilgili toplam ders oranları dokuz BBY bölümünde \%15'in üzerindedir. En yoğun zorunlu ders oranı \% 15,38 (Ankara Yıldırım Beyazıt Üniversitesi BBY) iken en düşük zorunlu ders oranı \%1,59 (Hacettepe Üniversitesi BBY)'dur. Seçmeli ders oranında ise bu durum tam tersini teşkil etmektedir. Yani en yoğun seçmeli ders oranı \%20,63 (Hacettepe Üniversitesi BBY) iken en düşük seçmeli ders oranı \%1,92 (Ankara Yıldırım Beyazıt Üniversitesi BBY)'dir.

Genel olarak BBY müfredatlarında lisans düzeyinde bilgisayar programları ve programlama dillerine yönelik toplam ders sayı ve oranları ile zorunlu ya da seçmeli ders durumları ele alındığında BBY bölümleri arasında farklılıkların olduğu anlaşılmaktadır.

Tablo 2: Bilgi ve Belge Yönetimi bölümleri lisans programı ders sayıları ve lisans programında bilgisayar programları ve programlama dilleri ile ilgili ders sayıları

\begin{tabular}{|c|c|c|c|c|c|c|c|c|c|c|c|}
\hline \multirow[b]{2}{*}{ Kuruluş Yeri } & \multicolumn{5}{|c|}{ Lisans Programı Dersleri } & \multicolumn{6}{|c|}{$\begin{array}{c}\text { Lisans Programında Bilgisayar } \\
\text { Programları ve Programlama Dilleri ile } \\
\text { İlgili Dersler }\end{array}$} \\
\hline & 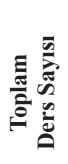 & 至 & 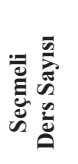 & 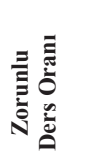 & 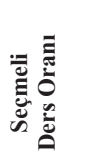 & 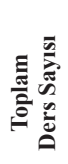 & 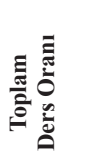 & 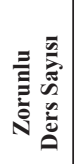 & 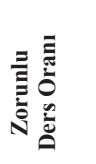 & 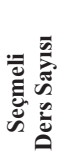 & 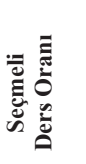 \\
\hline $\begin{array}{l}\text { Ankara Üniversitesi } \\
\text { BBY }\end{array}$ & 75 & 33 & 42 & $\% 44,00$ & $\% 56,00$ & 15 & $\% 20,00$ & 5 & $\% 6,67$ & 10 & $\% 13,33$ \\
\hline $\begin{array}{l}\text { İstanbul Üniversitesi } \\
\text { BBY }\end{array}$ & 78 & 36 & 42 & $\% 46,15$ & $\% 53,85$ & 8 & $\% 10,26$ & 6 & $\% 7,69$ & 2 & $\% 2,56$ \\
\hline $\begin{array}{l}\text { Hacettepe } \\
\text { Üniversitesi BBY }\end{array}$ & 63 & 18 & 45 & $\% 28,57$ & $\% 71,43$ & 14 & $\% 22,22$ & 1 & $\% 1,59$ & 13 & $\% 20,63$ \\
\hline $\begin{array}{l}\text { Marmara } \\
\text { Üniversitesi BBY }\end{array}$ & 62 & 30 & 32 & $\% 48,39$ & $\% 51,61$ & 11 & $\% 17,74$ & 3 & $\% 4,84$ & 8 & $\% 12,90$ \\
\hline $\begin{array}{l}\text { Atatürk Üniversite } \\
\text { BBY }\end{array}$ & 73 & 37 & 36 & $\% 50,68$ & $\% 49,32$ & 10 & $\% 13,70$ & 6 & $\% 8,22$ & 4 & $\% 5,48$ \\
\hline
\end{tabular}




\begin{tabular}{|l|c|c|c|c|c|c|c|c|c|c|c|}
\hline $\begin{array}{l}\text { Kastamonu } \\
\text { Üniversitesi BBY }\end{array}$ & 90 & 41 & 49 & $\% 45,56$ & $\% 54,44$ & 12 & $\% 13,33$ & 8 & $\% 8,89$ & 4 & $\% 4,44$ \\
\hline $\begin{array}{l}\text { Çankırı Karatekin } \\
\text { Üniversitesi BBY }\end{array}$ & 75 & 24 & 51 & $\% 32,00$ & $\% 68,00$ & 14 & $\% 18,67$ & 6 & $\% 8,00$ & 8 & $\% 10,67$ \\
\hline $\begin{array}{l}\text { Ankara Y1ldırım } \\
\text { Beyazıt Üniversitesi } \\
\text { BBY }\end{array}$ & 52 & 42 & 10 & $\% 80,77$ & $\% 19,23$ & 9 & $\% 17,31$ & 8 & $\% 15,38$ & 1 & $\% 1,92$ \\
\hline $\begin{array}{l}\text { İstanbul Medeniyet } \\
\text { Üniversitesi BBY }\end{array}$ & 84 & 36 & 48 & $\% 42,86$ & $\% 57,14$ & 14 & $\% 16,67$ & 6 & $\% 7,14$ & 8 & $\% 9,52$ \\
\hline $\begin{array}{l}\text { İzmir Kätip Çelebi } \\
\text { Üniversitesi BBY }\end{array}$ & 59 & 24 & 35 & $\% 40,68$ & $\% 59,32$ & 15 & $\% 25,42$ & 4 & $\% 6,78$ & 11 & $\% 18,64$ \\
\hline $\begin{array}{l}\text { Osmaniye Korkut } \\
\text { Ata Üniversitesi } \\
\text { BBY }\end{array}$ & 80 & 43 & 37 & $\% 53,75$ & $\% 46,25$ & 7 & $\% 8,75$ & 4 & $\% 5,00$ & 3 & $\% 3,75$ \\
\hline $\begin{array}{l}\text { Bartın Üniversitesi } \\
\text { BBY }\end{array}$ & 53 & 30 & 23 & $\% 56,60$ & $\% 43,40$ & 12 & $\% 22,64$ & 5 & $\% 9,43$ & 7 & $\% 13,21$ \\
\hline $\begin{array}{l}\text { İstanbul 29 Mayıs } \\
\text { Üniversitesi BBY }\end{array}$ & 58 & 46 & 12 & $\% 79,31$ & $\% 20,69$ & 16 & $\% 27,59$ & 8 & $\% 13,79$ & 8 & $\% 13,79$ \\
\hline
\end{tabular}

BBY bölümlerinin zorunlu ve seçmeli derslerinin yüzde oranları ve toplam ders sayıları Şekil 1'de sunulmuştur. Bölümlerin lisans programlarındaki zorunlu ders oranları \%28,57 (Hacettepe Üniversitesi BBY) ile \%80,77 (Ankara Yıldırım Beyazıt Üniversitesi BBY) arasında yer almaktadır. Zorunlu statüde en fazla derse sahip olan ilk üç bölüm, sırasıyla Ankara Yıldırım Beyazıt Üniversitesi BBY (\%80,77), İstanbul 29 Mayıs Üniversitesi BBY $(\% 79,31)$ ve Bartın Üniversitesi BBY $(\% 56,60)$ bölümleridir. En düşük orana sahip üç bölüm ise sırasıyla Hacettepe Üniversitesi BBY (\%28,57), Çankırı Karatekin Üniversitesi BBY $(\% 32,00)$ ve İzmir Kâtip Çelebi Üniversitesi BBY (40,68\%) bölümleridir. Seçmeli statüde en fazla ders oranına sahip ilk üç bölüm sırasıyla Hacettepe Üniversitesi BBY $(\% 71,43)$, Çankırı Karatekin Üniversitesi BBY $(\% 68,00)$ ve İzmir Kâtip Çelebi Üniversitesi BBY $(\% 59,32)$ 'dir. En düşük orana sahip bölümler ise Ankara Yıldırım Beyazıt Üniversitesi BBY (19,23\%) ve İstanbul 29 Mayıs Üniversitesi BBY $(\% 20,69)$ 'dir. 


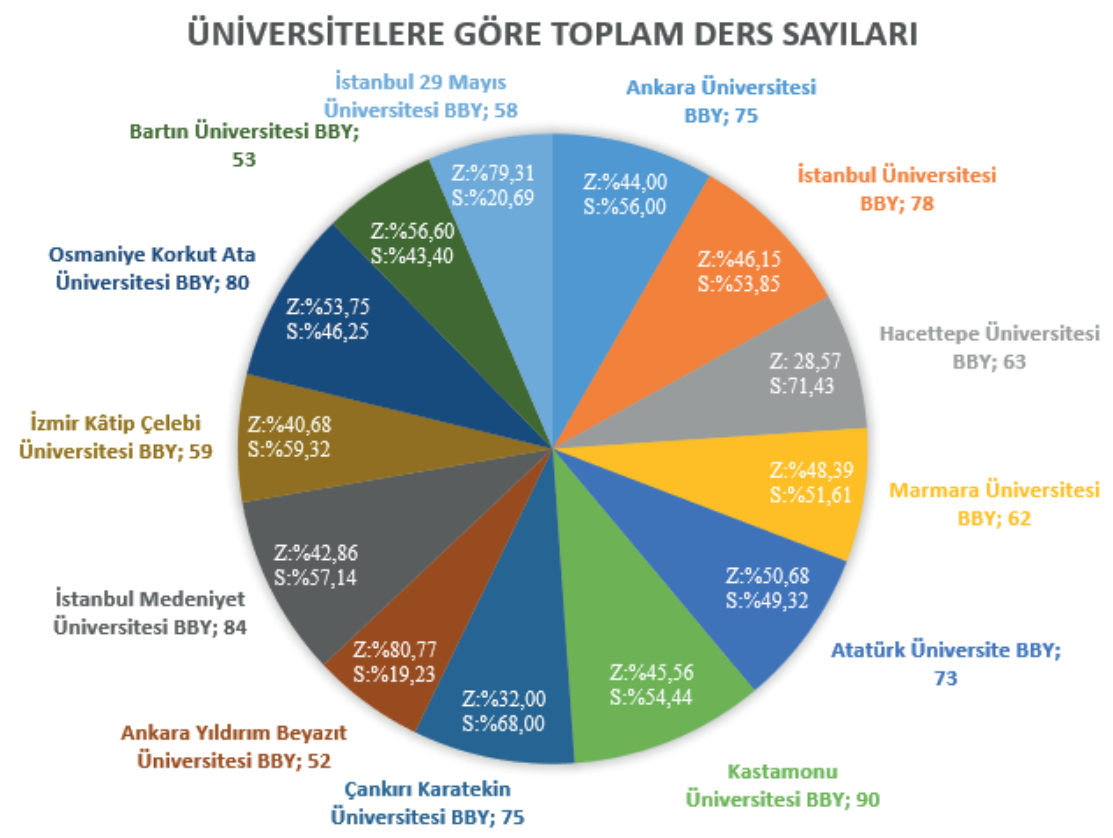

Şekil 1: BBY Bölümlerinin üniversitelere göre toplam ders sayıları

\subsection{Bilgisayar Programları ve Programlama Dillerine Yönelik Derslerin İçerikleri}

Yukarıda BBY bölümlerinin lisans düzeyinde toplam ders sayı ve oranları, bilgisayar programları ve programlama dillerine yönelik ders sayı ve oranları, bu sayı ve oranların zorunlu ya da seçmeli durumları değerlendirilmiştir. Bunlara ek olarak bölümlerde bilgisayar programları ve programlama dillerine yönelik derslerin içerikleri de incelenmiştir. Aşağıda ilgili bölümlerin web sayfalarından erişilen güncel ders içerikleri ele alınmıştır.

Ankara Üniversitesi Bilgi ve Belge Yönetimi Bölümü, zorunlu ve seçmeli ders adları Şekil 2'de verilmiştir. Derslerin içerikleri genel olarak şu şekillerde ele alınmıştır (Ders Listesi ve Kredilendirme, t.y.):

- "Ders kapsamında algoritma ve akış diyagramlalar [diyagramlar] anlatılacak, uygulamaları yapılacaktır. Sonrasında C\# programlama diline giriş yapılacak ve C\# ile uygulamalar geliştirilecektir".

- "Veri tabanlarına ilişkin temel kavramlar; İlişkisel veri modeli ve nesne uyarlı veri modeli) MS Visio ile tasarım; Veri tabanı yönetim sistemlerinin temel unsurları; Tasarım 
Metodolojileri (varlık-ilişki modeli, vb.); Uygulama; Veri Modelleri (ilişkisel ve nesne uyarlı veri modeli) MS Visio ile tasarım; Access üzerinde mantıksal şema oluşturma”.

- "Ders kapsamında C\# programlama dili ile masaüstü uygulamalar geliştirilecektir."

- “Metin verisinden özellik çıkarımı, işlevsel sözcüklerin belirlenmesi ve durma listesinin [mavi ekran hatası] oluşturulması, frekans hesaplamaları, gövdeleme, ağırlıklandırma, doküman sınıflama ve kümeleme. RapidMiner üzerinde uygulama yapılır”.

- “Derste, Büyük veri, büyük verinin özellikleri, büyük veri ile diğer veriler arasındaki farklar, neden veri madenciliğinin gerekli olduğu, nasıl veri madenciliği yapıldığ anlatılmaktadır".

- “Derste, e-belge özellikleri ve e-belge yönetimi uygulama yazılımları, elektronik belge yönetimi ve arşivleme sistemi (e-beyas), sistem bileşenleri ve sistem fonksiyonları, kurumsallaştırma ve kurumsal veri yönetimi, birim ve iş akış yönetimi, sistemde rol tanımlama ve aksiyonlar, kullanıcı yönetimi, gizlilik ve erişim yetkilendirmeleri, dosya ve saklama planı yönetimi, sistem ve kullanıcı eğitimleri, e-belge yönetiminde e-imza/mimza entegrasyonları ve e-imza kullanımı, sistemin standartlara uyumluluk denetimi, e-imza uyum denetimi, güvenlik ve yük testleri, iç ve diş sistem entegrasyonları, e-değerlendirme-ayıklama-imha işlemleri, sistemin teknik altyapı, işletim ve fonksiyon özellikleri, yeni versiyon-test-uygulama süreçleri “ anlatılmaktadır.

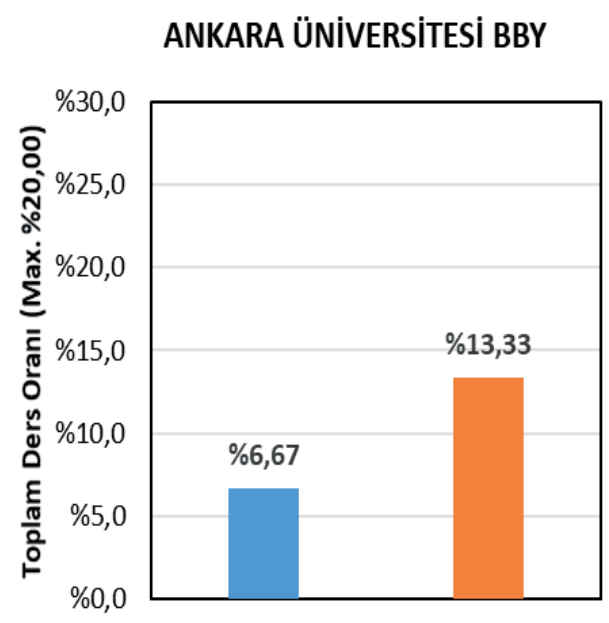

Zorunlu Dersler

BBY246 Algoritma ve Programlamaya Giriş

BBY353 Marc

BBY355 Veri Tabanı Tasarımı

BBY360 İstatistik

BBY459 Metadata

Seçmeli Dersler

BBY321 İşletmelerde Bilgi Sistemleri

BBY324 Veri Tabanı Yönetim Sistemleri

BBY335 Programlama

BBY364 Kullanıcı Deneyimi Tasarımı ve Bilgi Merkezleri

BBY374 Elektronik Belge ve Arşiv Yönetim Sistemleri

BBY410 Kütüphane Otomasyonu II

BBY411 Kütüphane Otomasyonu I

BBY428 Metin Analitiği

BBY429 Web Programlama

BBY448 Büyük Veri ve Veri Madenciliği

\# Zorunlu Ders Oranı

- Seçmeli Ders Oranı

Şekil 2: Ankara Üniversite BBY 
İstanbul Üniversitesi Bilgi ve Belge Yönetimi Bölümü, zorunlu ve seçmeli ders adları Şekil 3’te verilmiştir. Derslerin içerikleri genel olarak şu şekillerde ele alınmıştır (Bilgi ve Belge Yönetimi Lisans Programı, 2021):

- “Derste, dosya yönetim programları, veri tabanı yönetim programları, kelime işlem programları, sunum programları ve elektronik hesap tablosu programlarının tanıtılması" ele alınmaktadır.

- "Derste, web sayfalarını geliştirebilmek ve tasarlayabilmek için gerekli işlemlerini yapma yeterlikleri kazandırmak".

Bölümde, diğer derslerin yanışı sıra bilgisayarların doğrudan arşivlerde kullanımı ile ilgili bir ders de bulunmaktadır.

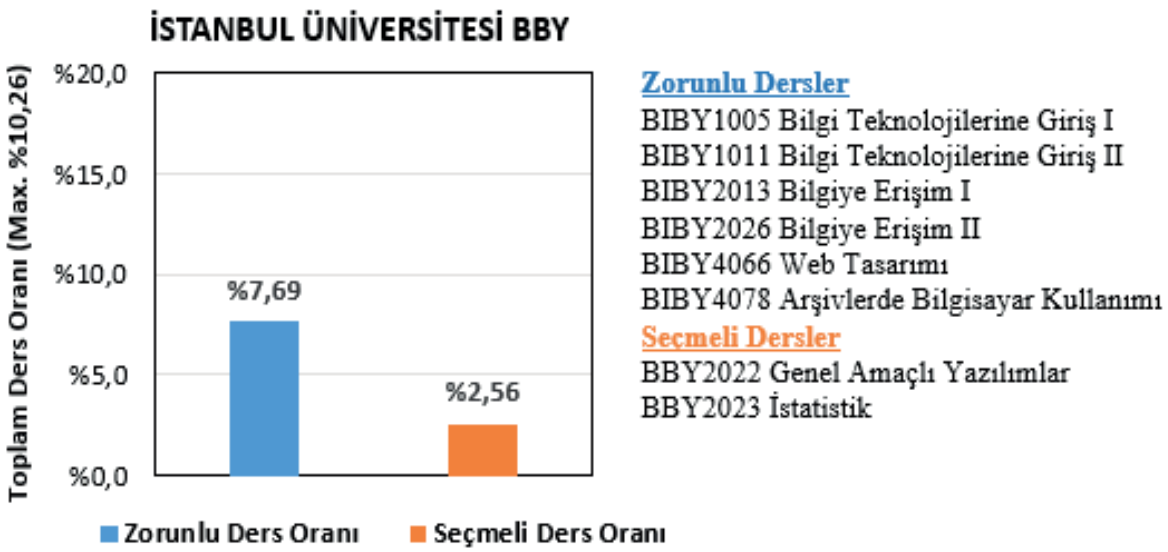

Şekil 3: İstanbul Üniversitesi BBY

Hacettepe Üniversitesi Bilgi ve Belge Yönetimi Bölümü, zorunlu ve seçmeli ders adları Şekil 4'te verilmiştir. Derslerin içerikleri genel olarak şu şekillerde ele alınmıştır (Bilgi Paketi, t.y.):

- “Derste, öğrencilere bilgisayarda problem çözme için temel yetilerin kazandırılması hedeflenmektedir".

- “Derste, nesne yönelimli yaklaşımların bilgisayarda problem çözmede öğrencilere kazandırmış olduğu temel yetiler” ele alınmaktadır.

- “Derste, öğrenciler bilginin görselleştirilmesi ve sunumu ile ilgili kavramları incelemektedir". 
- “Derste, Coğrafi Bilgi Sistemleri (CBS) ile ilgili temel bilgiler sunularak ve konu bilgi yönetimi açısından örneklerle ele alınmaktadır”.

- “Bu derste, semantik bilgi yönetimine giriş, ontoloji yönetimi, ontoloji geliştirme araçları, bilgi yönetimi için ontolojiler, semantik webde bilgi keşfi ve sosyal ağları kullanma" gibi konular incelenmektedir.

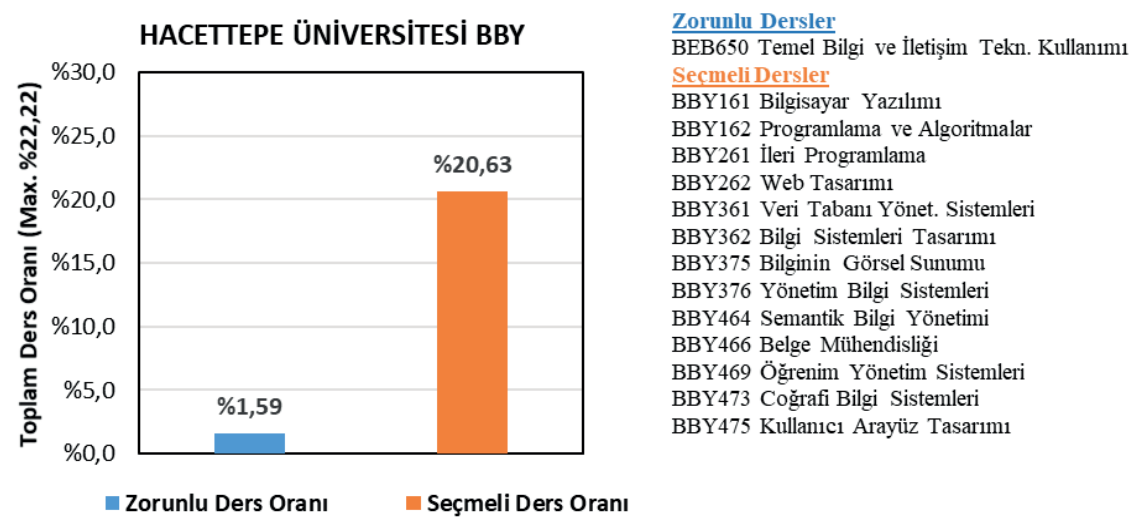

Şekil 4: Hacettepe Üniversitesi BBY

Marmara Üniversitesi Bilgi ve Belge Yönetimi Bölümü, zorunlu ve seçmeli ders adları Şekil 5'te verilmiştir. Derslerin içerikleri genel olarak şu şekillerde ele alınmıştır (Lisans Program1, 2021):

- 'Dersin içeriği, Aktif Sunucu Sayfası (ASP), Microsoft'un sunduğu karşılıklı etkileşimli (interaktif) sayfalar yapabilmek için kullanılabilecek yeni bir web teknoloji dilinin eğitiminin verilmesidir".

- “Derste, temel çoğul ortam kavramlarını tanıtmak, öğrencilere ses, konuşma, görüntü ve video gösterimi, kodlama, işleme ve analizi yöntemleri konularında temel bilgileri aktarmak. Öğrencilerin çoğul ortam sistemleri tasarlayabilmeleri için gerekli olan temel bilgileri vermek".

- "Bu derste, öğrenciler veri tabanı tasarımı ile ilgili temel ve ileri konuları öğrenir. Ayrıca, öğrencilere veri tabanı yönetim sistemi yazılım paketi öğretilmekte ve gerçek bir veri tabanı tasarlayacakları bir dönem projesi verilmektedir".

- “Derste, dijital alanda üretilen bilgiyi yönetmek, elektronik bilgiyi takip etmek, değişen teknolojiye adaptasyon, yeni uygulamalar, tanımlar ve standartlar gibi konular 
incelenmektedir. Ders; dijital kütüphaneciliğin, elektronik ortamdaki kütüphanecilik uygulamalarının anlaşılması ve bilgi ve bilgi kaynaklarının yönetimi becerisinin kazanılması konusunda katkıda bulunacaktır".

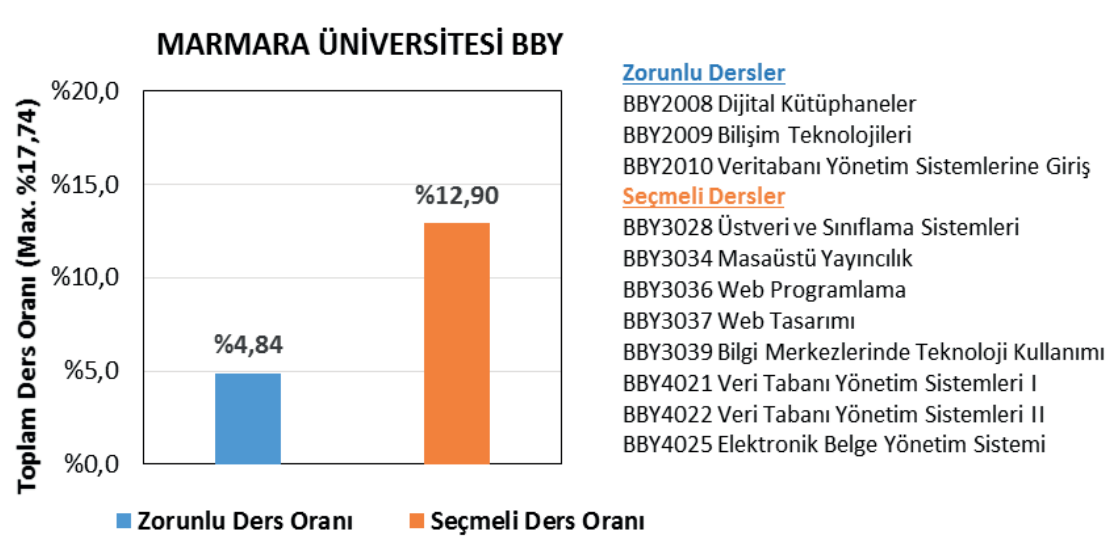

Şekil 5: Marmara Üniversitesi BBY

Atatürk Üniversitesi Bilgi ve Belge Yönetimi Bölümü, zorunlu ve seçmeli ders adları Şekil 6'da verilmiştir. Derslerin içerikleri genel olarak şu şekillerde ele alınmıştır (Bilgi ve Belge Yönetimi Programı 1089, (2021):

- "Bu ders, bilgisayar programlamaya giriş dersidir. Bu derste öğrenciler algoritma kurarak ve temel düzeyde programlar yazma yetkinliği edineceklerdir”.

• “Ders, elektronik belge yönetimi ve arşiv yönetimi teknik ve uygulamalarını içerir”.

- “Ders öğrencilerin web editörünü kullanarak web sayfası tasarlayabilmelerine katkı sağlayacaktır".

- “Derste, veri tabanı tasarlama, veri tabanı yönetimsel fonksiyonlarını kullanma yeterliliklerini kazanma ve bu konuda projeler hazırlama konuları işlenmektedir”. 


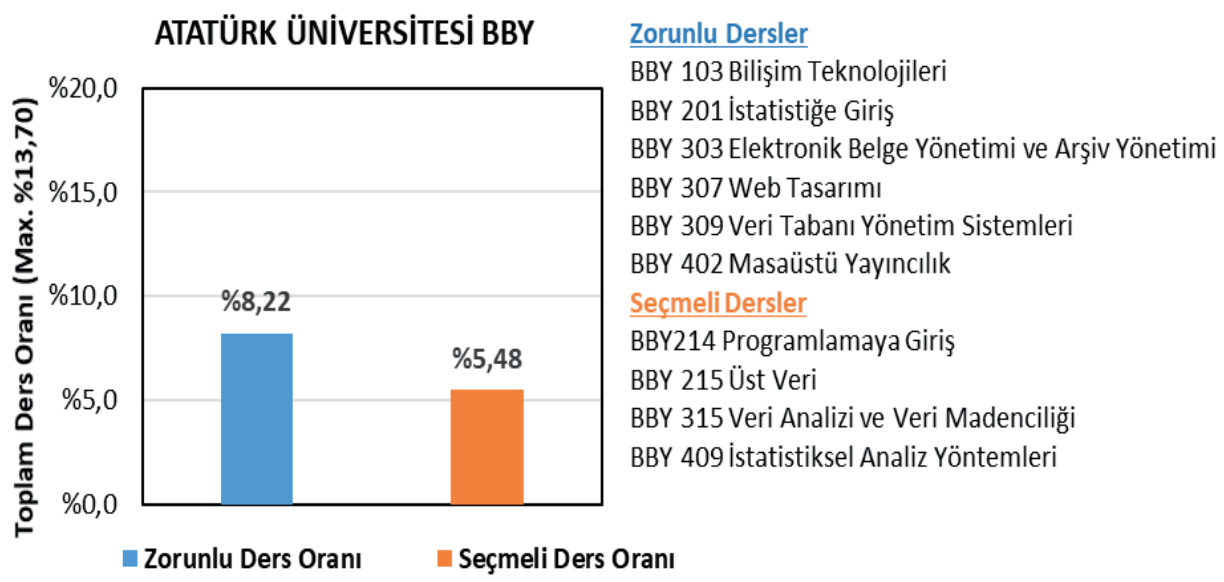

Şekil 6: Atatürk Üniversitesi BBY

Kastamonu Üniversitesi Bilgi ve Belge Yönetimi Bölümü, zorunlu ve seçmeli ders adları Şekil 7'de verilmiştir. Derslerin içerikleri genel olarak şu şekillerde ele alınmıştır (Bilgi-veBelge-Yonetimi-Ders-İcerikleri, t.y.):

- "Sayısal bilginin depolanması, tanımlanması/düzenlenmesi ve erişimi bağlamında ele alınan bu derste sayısal kütüphane ve arşivlerin tarihsel gelişimi, tanım ve temel kavramları, amaç ve işlevleri, temel özellikleri kurumsal ve uygulamalı olarak incelenmektedir. Bu çerçevede bilgi teknolojileri eşliğinde bilgi mimarisi tanımı ve temel kavramları, ilkeleri, Bilgi ve Belge Yönetimi ile ilişkisi, uygulamaları değerlendirilmektedir”.

- "Veri tabanları ve yönetim sistemleri ile ilgili temel kavramlar, bilgi altyapısını oluşturan teknolojiler, veri modelleri, tasarım yöntemleri, önemi, temel özellikleri ve kullanımı bilgi ve belge merkezleri açısından incelenecek; veri tabanı oluşturma aşamaları, veri tabanı yönetiminin önemi konusu örnekleri ile incelenecektir”.

- "Bu derste öğrenciler gerçek ağ verilerini toplama, analiz etme ve yorumlama kapasitesine sahip olacaklardır. Veri toplama ve görselleştirme tekniği olarak Pajek, Gephi kullanılacaktır". 


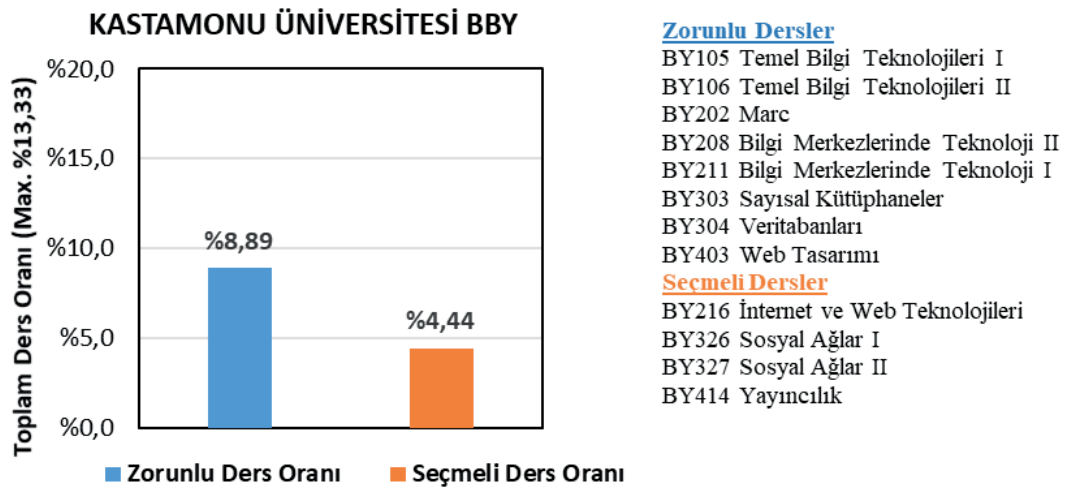

Şekil 7: Kastamonu Üniversitesi BBY

Çankırı Karatekin Üniversitesi Bilgi ve Belge Yönetimi Bölümü, zorunlu ve seçmeli ders adları Şekil 8'de verilmiştir. Derslerin içerikleri genel olarak şu şekillerde ele alınmıştır (Bilgi ve Belge Yönetimi, 2017):

- “Derste, Linux dağıtımlarını seçme, kurma ve kullanma konuları ele alınmaktadır”.

- "Bu ders kapsamından algoritma yapı taşları, akış diyagramları, değişkenler, veri türleri, aritmetik işlemler, kontrol işlemleri, döngü işlemleri ve fonksiyon konuları uygulamalı olarak işlenmektedir".

- "Bu derste, Java ile nesne yönelimli programlama teknikleri ele alınmaktadır".

- “Bu derste, HTML, PHP, SQL, Javascript ve gerekli web yazılımlarının öğrenilmesi için gerekli programları kullanma, dinamik web siteleri oluşturma ve çevrimiçi bilgi döngüsü süreci konularını anlama ele alınmaktadır”.

- "Bu derste temel istatistik terminolojileri hakkında bilgiler verildikten sonra; merkezi eğilim ölçütlerinin hesaplamasına yönelik uygulamalar yapılmaktadır. Aynı zamanda bu derste SPSS yazılımı üzerinde parametrik ve parametrik olmayan testlere yönelik örnek çalışmalar ile; Google Drive ve surveey.com gibi dinamik istatistik derleme ve analizleme platformlarının kullanımı üzerinde pratik yapılmaktadır”.

- “Derste, coğrafi bilgi sistemlerinin kullanım mantığını kavrama, proje yönetim sürecini açıklama, CBS teknik ve teknolojilerini öğretme, CBS veri kaynaklarını tanıtma, üst veri ve veri tabanlarını öğrenme konuları ele alınmaktadır"

- “Bu derste veri madenciliği süreci, veri madenciliğinde uygun yazılımlar, veri madenciliği modelleri, örnek araştırma modelleri ve uygulamaları işlenecektir”. 


\section{ÇANKIRI KARATEKIN ÜNIVERSITESI BBY}

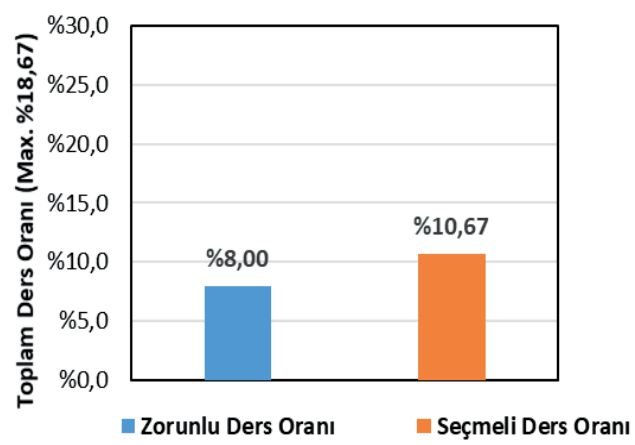

Zorunlu Dersler

BBY 106 Bilgi ve İletişim Teknolojileri

BBY 107 Bilișim Teknolojileri

BBY205 Algoritma ve Veri Yap1s1

BBY206 Veri Tabanlarına Giriș

BBY304 Web Programlama ve Tasarım

BBY405 Kütüphane Otomasyonu

Secmeli Dersler

BBY212 Nesne Yönelimli Programlama

BBY214 Elektronik Yayınlıc1k

BBY219 Unıx/Linux Sistem Yönetimi

BBY309 Üstveri

BBY314 Bilgi Merkezlerinde İstatistik

BBY320 Bilgi Merkezlerinde Coğrafi Bilgi Sistemleri

BBY321 Bilgi Erişim

BBY412 Veri Madenciliği

Şekil 8: Çankırı Karatekin Üniversitesi BBY

Ankara Yıldırım Beyazıt Üniversitesi Bilgi ve Belge Yönetimi Bölümü, zorunlu ve seçmeli ders adları Şekil 9'da verilmiştir. Derslerin içerikleri genel olarak şu şekillerde ele alınmıştır (Bilgi ve Belge Yönetimi(TR)-Dersler, (t.y.):

- "Bu derste, kavram olarak veri tabanı, veri tabanı yönetim sistemleri, veri tabanı analiz süreci, varlık-ilişki diyagramları, veri tabanı tasarım süreci, mantıksal veri tabanı tasarımı, ilişkisel veri tabanı tasarımı, normalleştirme; VTYS'nin yapısı ve tasarımı, fiziksel veri tabanı tasarımı, sorgu ve veri düzenleme dilleri, SQL ve veri tabanı yönetimi konuları işlenmektedir”.

- “Derste, algoritma ve programlamanın temel kavramlarını kazandırma, programlama dilinin temellerini öğretme ve program geliştirme konuları ele alınmaktadır”.

• " "Bu derste, web sitesi tasarlama ve yönetme konuları işlenmektedir". 


\section{ANKARA YILDIRIM BEYAZIT ÜNIVERSITESI BBY}

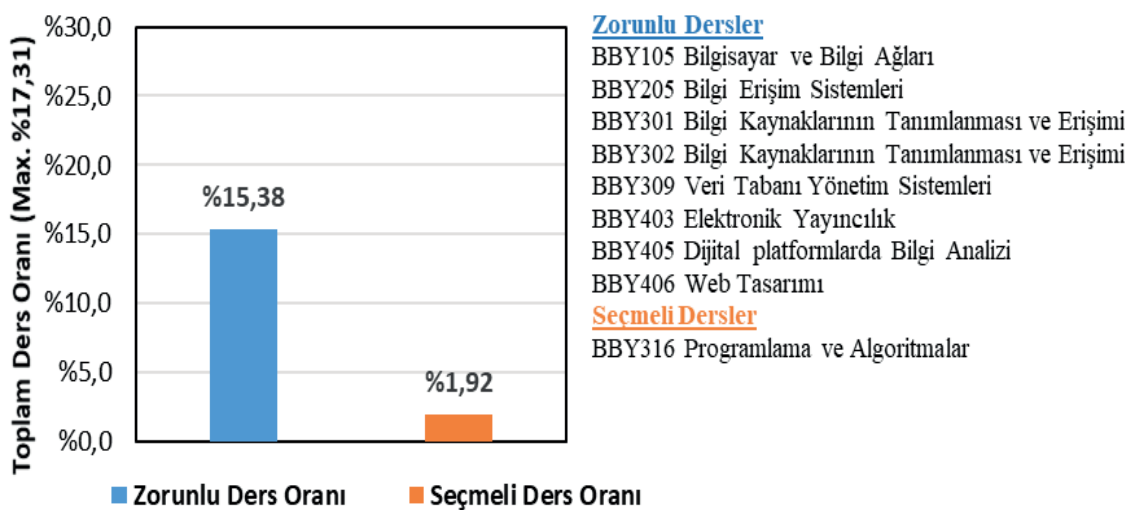

Şekil 9: Ankara Yıldırım Beyazıt Üniversitesi BBY

İstanbul Medeniyet Üniversitesi Bilgi ve Belge Yönetimi Bölümü, zorunlu ve seçmeli ders adları Şekil 10'da verilmiştir. Derslerin içerikleri genel olarak şu şekillerde ele alınmıştır (Bilgi ve Belge Yönetimi(TR)-Dersler, 2020):

- "Derste, ilişkisel veri tabanı tasarımında basit teorik altyapıyı oluşturma konusu ele alınmaktadır".

- "Derste, derme sayıları ve grafikleri veri analizi; iç ortam zaman sıcaklık ve bağıl nem ölçümleri ve grafikleri veri analizi; sınav notları standart sapma medyan mod frekans tabloları veri analizi; https://www.chartgo.com/ sitesi veri analizi; https://www.easel. ly/ veri analizi; kitap/yayınevi veri analizi; BBY uzmanı pozisyon/ kadro veri analizi konuları incelenmektedir".

- "Derste, veri madenciliği, veri hazırlama teknikleri, istatistiksel öğrenme teorisi, kümeleme metotları, karar ağaçları ve karar kuralları, birliktelik kuralları, istatistiksel sınıflandırma, sınıflandırma algoritmaları-kümeleme yöntemleri, olan küp ve raporları (veri ambarı) veri-veri dönüşümleri, veri indirgeme, veri madenciliğinde yapay sinir ağları, endüstride veri madenciliği uygulamaları, müşteri ilişkileri yönetimi, veri tabanı yönetim sistemlerinde veri madenciliği uygulamaları (uygulama alanları), web madenciliği ve sosyal medya madenciliği, metin madenciliği, veri madenciliği yazılım programların genel tanıtımı işlenmektedir".

- 'Derste, CBS'nin tarihçesi, CBS'nin temel ilkeleri ve faydaları, CBS'nin temel bileşenleri, mekânsal veri tipleri, CBS'de veri modelleri, CBS veri kaynakları, sorgulama, analizler ve veri görselleştirme konuları ele alınmaktadır". 


\section{ISTANBUL MEDENIYET ÜNIVERSITESI BBY}

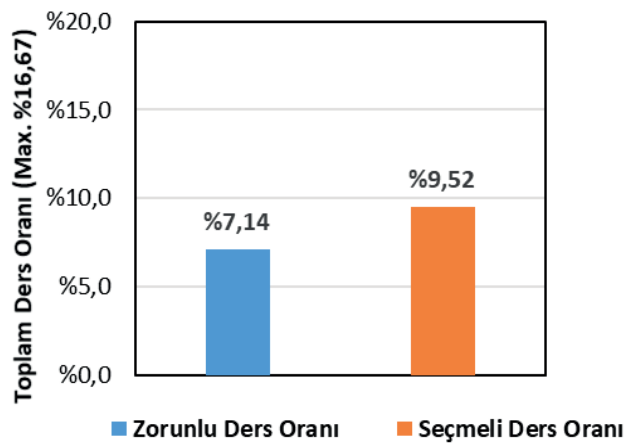

Zorunlu Dersler

BBY113 Bilgi ve Belge Teknolojileri

BBY207 Veri Tabanı Uygulamalar1

BBY208 Veri Tabanı Uygulamaları II

BBY300 Veri Analizi Ve Görselleștirme

BBY307 İstatistik

BBY414 Web Tasarımı

Secmeli Dersler

BBY216 Bilgi Sistemleri Uygulamalar1

BBY218 Metadata

BBY315 Elektronik ve Dijital Kaynaklar

BBY326 Veri Tabanı Yönetimi

BBY327 Elektronik Bilgi ve İçerik Yönetimi

BBY328 Veri Madenciliği

BBY407 Coğrafi Bilgi Sistemleri

BBY415 Semantik Bilgi Yönetimi

Şekil 10: İstanbul Medeniyet Üniversitesi BBY

İzmir Kâtip Çelebi Üniversitesi Bilgi ve Belge Yönetimi Bölümü, zorunlu ve seçmeli ders adları Şekil 11'de verilmiştir. Derslerin içerikleri genel olarak şu şekillerde ele alınmıştır (Bilgi ve Belge Yönetimi Bölümü/Lisans, t.y.).

- “Üst veri kavramı; onun çeşitleri ve nitelikleri; üst verinin belge yönetimi ile olan ilişkisi; üst veri standartları ve bu standartlara ilişkin uygulamalar bu dersin içeriğini oluşturmaktadır”.

- “Bilgi Yönetimi Kavramları dersi kapsamında, öğrencilere bilgi yönetimi ile ilgili ilk olarak; bilgi ekolojisi, bilgi ekonomisi, bilgi erişim, gibi temel ve ilişkili kavramlar ele alınmaktadır. Ardından veri yönetimi ile ilgili; açık veri, veri görselleştirme, veri madenciliği gibi güncel konular ve gelişmelerle ilgili bilgiler verilmektedir”.

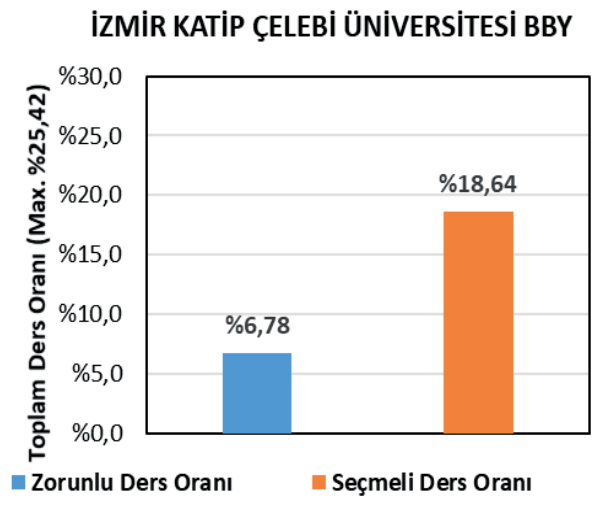

Şekil 11: İzmir Kâtip Çelebi Üniversitesi BBY

\author{
Zorunlu Dersler \\ BBY 104 Bilgi Yönetimi Kavramları \\ BBY 107 Bilgi Teknolojilerine Giriş \\ BBY 301 istatistik \\ BBY 303 Bilgi Sistemleri Tasarımı ve Yönetimi \\ Seçmeli Dersler \\ BBY 222 Web Tasarımı \\ BBY 223 Algoritma ve Programlamaya Giriş \\ BBY 321 Sosyal Ağ Analizine Giriş \\ BBY 323 Masaüstü Yayıncılık \\ BBY 329 Üst Veri \\ BBY 328 Sayısal Yöntemler \\ BBY 332 Elektronik Belge Yönetimi ve Arşivleme Sistemi Uygı \\ BBY 421 Veri Madenciliği \\ BBY 429 İçerik Yönetimi \\ BBY 431 Coğrafi Bilgi Sistemleri \\ BBY 434 Veri İletişimi ve İşbirliği
}


Osmaniye Korkut Ata Üniversitesi Bilgi ve Belge Yönetimi Bölümü, zorunlu ve seçmeli ders adları Şekil 12'de verilmiştir. Derslerin içerikleri genel olarak şu şekillerde ele alınmıştır (Bölüm Güncel Ders Müfredat1, 2021):

- “Bu derste, HTML, PHP, SQL, Javascript ve gerekli web yazılımlarının öğrenilmesi için gerekli programları kullanma ve dinamik web siteleri oluşturma konuları ele alınmaktadır".

- "Bu ders kapsamında veri madenciliği süreci, veri madenciliğinde uygun yazılımlar, veri madenciliği modelleri, örnek araştırma modelleri ve uygulamaları işlenecektir”.

\section{OSMANIYE KORKUT ATA ÜNIVERSITESI BBY}

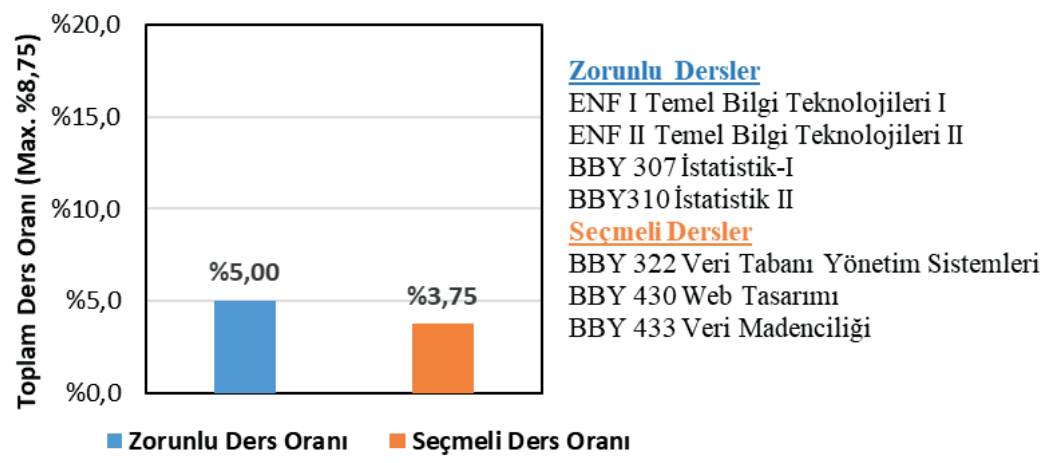

Şekil 12: Osmaniye Korkut Ata Üniversitesi BBY

Bartın Üniversitesi Bilgi ve Belge Yönetimi Bölümü, zorunlu ve seçmeli ders adları Şekil 13 'te verilmiştir. Derslerin içerikleri genel olarak şu şekillerde ele alınmıştır (Bilgi ve Belge Yönetimi Bölümü/Bilgi ve Belge Yönetimi Pr., t.y.):

- "Bu derste öğrenciler, algoritmanın ne olduğunu kavrar, günlük ve kurumsal olan tüm işlerdeki basamaklandırmaları algoritmik olarak yazabilir. Veri tabanı sistemleri ve kütüphane sistemlerindeki algoritmayı öğrenirler”.

- “Öğrenciler, araştırma yapması beklenen bir birey akademik yazım şartlarını etik, etik ihlal ve araştırma ve araştırmacıya saygı çerçevesinde bilgiye sahiptir. Bu nedenle kaynak yönetimi ile bu alanda kullanılan intihal araçlarını kullanmayı öğrenirler”.

- “Bu derste öğrenci, Html dilini bilir, basit kodlar yazarak ilk dönem web sitelerini oluşturur, css kullanım bilgisine sahip olur, güncel programları kullanarak çağdaş web siteleri oluşturabilir"

- Dersin içeriği; verinin görselleştirilmesinin günüz toplumunda ve çağında önemi verilir, veri görselleştirilmesinde en etkili programların sunulması ve kullanılması ele alınır”.

- "Bu derste öğrenci, bilgi merkezlerinde kullanılan otomasyon sistemlerini ve içeriklerini genel olarak tanır”. 


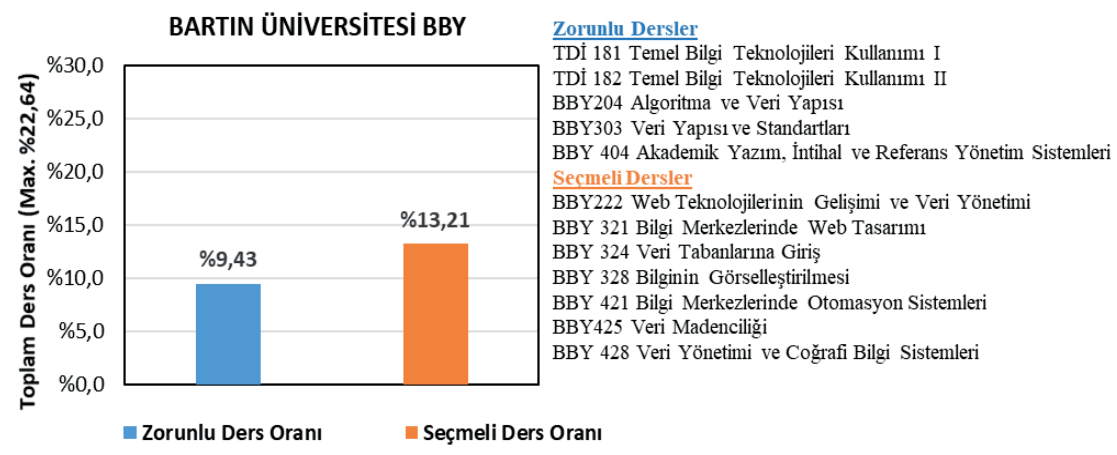

Şekil 13: Bartın Üniversitesi BBY

İstanbul 29 Mayıs Üniversitesi Bilgi ve Belge Yönetimi Bölümü, zorunlu ve seçmeli ders adları Şekil 14'te verilmiştir. Derslerin içerikleri güncelleme aşamasında olduğundan dolayı erişim sağlanamamıştır (Öğretim Programı, 2021).

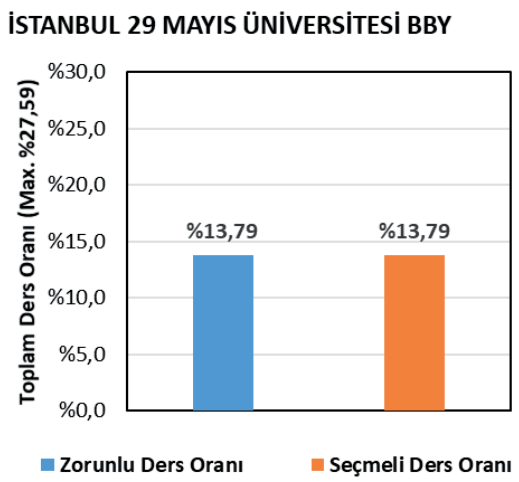

Zorunlu Dersler BBY107 Temel Bilgi Teknolojileri I BBY108 Temel Bilgi Teknolojileri II BBY208 Kamusal Bilgi ve Elektronik Belge Yönetimi BBY209 Bilgisayar Yazılımları I BBY210 Bilgisayar Yazılımları II BBY302 Elektronik Yayınc1lik BBY306 Veri Tabanı Yönetimi BBY401 Büyük Veri ve Yapay Zekâ Uygulamaları Secmeli Dersler BBY334 Algoritma ve Programlama BBY335 Ocr Sistemleri BBY338 Yayıncılık ve Editörlük BBY443 Yazılım Kodlama BBY444 Web Tasarımları BBY445 Veri Tabanı Sistemleri BBY447 Semantik Bilgi Yönetimi BBY449 Etkili Sunum Teknikleri

Şekil 14: İstanbul 29 Mayıs Üniversitesi BBY

\section{Tartışma}

Bölümlerin lisans ders programlarında, Algoritmalar ve Programlamaya Giriş, Veri Tabanı Tasarımı, Programlama, Web Programlama, Metin Analitiği, Büyük Veri ve Veri Madenciliği, Programlamaya Giriş, Algoritma ve Veri Yapısı, Veri Madenciliği, Veri Tabanlarına Giriş, Web Programlama ve Tasarım, Nesne Yönelimli Programlama, Bilgi Merkezlerinde Coğrafi Bilgi Sistemleri, Bilgisayar Yazılımı, İçerik Yönetimi, UNIX, Linux Sistem Yönetimi, İleri Programlama, Bilginin Görsel Sunumu, Metadata, Veri Analizi ve Görselleştirme, Sosyal Ağlar, OCR Sistemleri, Yazılım Kodlama, Veri Tabanı Yönetim Sistemleri, Üst Veri, Sayısal 
Yöntemler gibi derslerin daha fazla yer aldığı görülmektedir. Ayrıca dört bilgi ve belge yönetimi bölümlerinde arşivcilik alanında bilgisayar programları kullanımına yönelik dersler de bulunmaktadır. Ankara Üniversitesi BBY, İstanbul Üniversitesi BBY, Atatürk Üniversitesi BBY ve İzmir Kâtip Çelebi Üniversitesi BBY bölümlerinde bu alanda dersler verilmektedir.

Çalışmada elde edilen bulguların tartışması maddeler halinde verilmiştir:

- $\quad$ BBY bölümleri lisans ders müfredatlarında toplam ders sayıları arasında büyük farklılıklar olduğu görülmektedir. Toplam ders sayısı 52 ile 90 arasında değişkenlik göstermektedir.

- Bölümlerdeki toplam ders sayıları, zorunlu ve seçmeli ders sayı ve oranları, bölümlerin eski tarihli ya da yeni tarihli kurulmaları açısından bir ilişki bulundurmamaktadır.

- Bölümlerin zorunlu ve seçmeli ders sayı ve oranları arasında da farklılıklar bulunmaktadır. En yüksek zorunlu ders oranına sahip bölüm Ankara Yıldırım Beyazıt Üniversitesi BBY $(\% 80,77)$ iken en düşük zorunlu ders oranı Hacettepe Üniversitesi BBY $(\% 28,57)$ bölümüdür. Bu oransal farklılık seçmeli ders oranları için de geçerlidir.

- Bölümlerin bilgisayar programları ve programlama dilleriyle alakalı ders sayıları, bu sayıların toplam ders sayılarına oranları ve ders içeriklerine bakıldığında bölümler arası gelişmelerin takip edildiği anlaşılmaktadır.

- Bölümler arasında bilgisayar programları ve programlama dilleriyle alakalı zorunlu ve seçmeli ders durumlarında önemli farklılıklar bulunmaktadır. Bölümlerin bu alanla ilgili derslerinin daha çok seçmeli statüsünde yer aldığı görülmektedir.

- $\quad$ BBY bölümlerinde bilgisayar programları ve programlama dilleriyle alakalı ders çeşitliliğinin artması ya da azalması konusunda önemli noktalardan biri de öğretim elemanlarının uzmanlık alan tercihlerinin belirleyici olmasıdır.

- Farklı disiplinler ile disiplinler arası iş birliği çalışmalarının yapıldığı anlaşılmaktadır.

- Tüm lisans bilgi ve belge yönetimi bölümleri bilgisayar programları ve programlama dilleriyle alakalı en az yedi derse sahiptir. Fakat bu durumun bölüm bazında gelecek yılların getireceği yenilikler açısından yeterli görülmeyeceği düşünülmektedir.

- Lisans müfredatları aralıklarla güncellenmiş ve güncellenmeye devam etmektedir.

- Alana dair yurtiçi ve yurtdışı bölümlerin takibinin yapılmaya çalışıldığı anlaşılmaktadır.

\section{SONUÇ}

Genel olarak bakıldığında bazı bölümlerin müfredatlarında bilgisayar programları ve programlama dillerine yönelik derslere daha fazla ağırlık verildiği görülmektedir. Bu konudaki ders çeşitliliğinin öğretim elemanı sayısı ve uzmanlık alanlarına bağlı olarak değişiklik gösterdiği 
düşünülmektedir. Yine de ders programlarında geliştirme çalışmaları yapıldığı görülmektedir. Programlamaya dair derslerin daha çok seçmeli ders statüsünde yer aldığı tespit edilmiştir. Bilgisayar programları ve programlama dilleriyle ilgili derslerin sayılarının, seçmeli ders sayısı fazla olan bölümlerde daha çok yer aldığı tespit edilmiştir. Bu durumun daha çok müfredattaki seçmeli ders çeşitliliğinden kaynaklandığı düşünülmektedir. Bölümlerin, bilgisayar programları ve programlama dilleriyle ilgili olarak artı ve eksi yönlerini daha fazla ortaya koyması gerekmektedir. Bilgisayar programları ve programlama dilleriyle ilgili derslerde daha fazla uygulamaya imkân verilmesi gerektiği düşünülmektedir. Bölüm öğrencilerinin bilgisayar programları ve programlama dilleri ile ilgili dersleri tercih etmelerine yönelik teşvik edilmesi gerekmektedir. Bilgisayar programları ve programlama dilleriyle alakalı daha fazla akademik çalışmanın yapılması disiplinler arası iş birliği çalışmalarını kuvvetlendirmesi açısından önemli olacaktır.

Hakem Değerlendirmesi: Dış bağımsız.

Çıkar Çatışması: Yazar çıkar çatışması bildirmemiştir.

Finansal Destek: Yazar bu çalışma için finansal destek almadığını beyan etmiştir.

Peer-review: Externally peer-reviewed.

Conflict of Interest: The author has no conflict of interest to declare.

Grant Support: The author declared that this study has received no financial support.

\section{Kaynakça/References}

Ankara Üniversitesi Bilgi ve Belge Yönetimi Bölümü. (t.y.a). Ders listesi ve kredilendirme. http://bbs.ankara. edu.tr/Ders_Plani.aspx?bno=1616\&bot=213 adresinden erişildi.

Ankara Üniversitesi Bilgi ve Belge Yönetimi Bölümü. (t.y.b). Genel bilgiler. http://bilgibelge.humanity.ankara. edu.tr/hakkimizda/genel-bilgiler/ adresinden erişildi.

Ankara Yıldırım Beyazıt Üniversitesi Bilgi ve Belge Yönetimi Bölümü. (t.y.). Dersler. https://obs.aybu.edu. tr/oibs/bologna/index.aspx?lang=tr\&curOp=showPac\&curUnit=02\&curSunit=5406\# adresinden erişildi.

Ankara Yıldırım Beyazıt Üniversitesi Bilgi ve Belge Yönetimi Bölümü. (2020). Akademik kadro. https://aybu. edu.tr/bby/tr/sayfa/1233/Akademik-Kadro adresinden erişildi.

Atatürk Üniversitesi Bilgi ve Belge Yönetimi Bölümü. (2021). Ders programı. https://obs.atauni.edu.tr/moduller/ dbp/eobs/birimDetay/1089/Bilgi\%20ve\%20Belge\%20Y\%C3\%B6netimi\%20Program\%C4\%B1\%20 (1089) adresinden erişildi.

Atılgan, D. (1995). Türkiye'de kütüphaneciliğin gelişimi. Türk Kütüphaneciliği, 9(1), 10-20. http://www. tk.org.tr/index.php/TK/article/view/972/963 adresinden erişildi.

Bartın Üniversitesi Bilgi ve Belge Yönetimi Bölümü. (t.y.a). Tarihçe. https://bilgibelge.bartin.edu.tr/tarihce. html adresinden erişildi.

Bartın Üniversitesi Bilgi ve Belge Yönetimi Bölümü. (t.y.b). Bilgi ve Belge Yönetimi Bölümü/Bilgi ve Belge Yönetimi $P r$. http://ubys.bartin.edu.tr/AIS/OutcomeBasedLearning/Home/Index?id=548\&culture=tr-TR adresinden erişildi. 
Baydur, G. ve Külcü, Ö. (2007). Arşivcilik eğitimi: Hacettepe Üniversitesi deneyiminin ardından. S. Kurbanoğlu, Y. Tonta ve U. Al (Yay. haz.), Değişen Dünyada Bilgi Yönetimi Sempozyumu, 24-26 Ekim 2007, Ankara Bildiriler içinde (ss. 24-31). Ankara: H.Ü. Bilgi ve Belge Yönetimi Bölümü.

Çakın, İ. (2005). Cumhuriyet’ten günümüze bilgi profesyonellerinin eğitiminde başlıca yönelişler. Türk Kütüphaneciliği, 19(1), 7-24. http://www.tk.org.tr/index.php/TK/article/view/16/17 adresinden erişildi.

Çakın, İ. (2012). Bilgi profesyonellerinin eğitiminde 40 yıl: Hacettepe Üniversitesi lisans programındaki değişiklikler. Türk Kütüphaneciliği, 26(2), 262-290. https://dergipark.org.tr/tr/download/article-file/811839 adresinden erişildi.

Çankırı Karatekin Üniversitesi Bilgi ve Belge Yönetimi Bölümü. (2021). Bölüm tanıtımı. https://bilgibelge. karatekin.edu.tr/bolum-tanitimi-16753-sayfasi.karatekin adresinden erişildi.

Çankırı Karatekin Üniversitesi. (2017). Bilgi ve Belge Yönetimi Bölümü. https://bbs.karatekin.edu.tr/derskatalog. aspx?bkod $=06 \&$ fkod $=06$ adresinden erişildi.

Ersoy, H. Madran, R. O. ve Gülbahar, Y. (2011). Programlama dilleri öğretimine bir model önerisi: Robot programlama. M. Akgül, E. Derman, A. Özgit, U. Çağlayan, M. Ertürkler ve M. Karakaplan (Ed.), Akademik Bilişim'11 XIII. Akademik Biliş̧im Konferansı bildirileri, 2-4 Şubat 2011 içinde (ss. 785-790). Malatya: İnönü Üniversitesi.

Hacettepe Üniversitesi. (t.y.a). Bilgi paketi. https://bilsis.hacettepe.edu.tr/oibs/bologna/index. aspx?lang=tr\&curOp=showPac\&curUnit $=520 \&$ curSunit=396\# adresinden erişildi.

Hacettepe Üniversitesi. (t.y.b). Program hakkında genel bilgiler. http://www.bby.hacettepe.edu.tr/page. php?x=4Ijrq93wGiE8u9WJGNPxtWFV88kWHSgKQhS3O5Zv0is\% adresinden erişildi.

Hosseini, R., Akhuseyinoglu, K., Brusilovsky, P., Malmi, L., Pollari-Malmi, K., Schunn, C., ve Sirkiä, T. (2020). Improving engagement in program construction examples for learning python programming. International Journal of Artificial Intelligence in Education, 30(2), 299-336. doi: 10.1007/s40593-020-00197-0

İstanbul 29 Mayıs Üniversitesi. (2021a). Bilgi ve Belge Yönetimi Bölümü. http://universitetercihleri.com/ video/14293/Bilgi-ve-Belge-Yonetimi-Bolumu.html adresinden erişildi.

İstanbul 29 Mayıs Üniversitesi. (2021b). Öğretim programı. https://bby.29mayis.edu.tr/tr/ogretim-programi adresinden erişildi.

İstanbul Medeniyet Üniversitesi Bilgi ve Belge Yönetimi Bölümü. (2020). Ders programı. https://obs.medeniyet. edu.tr/oibs/bologna/index.aspx?lang=tr\&curOp=showPac\&curUnit=01\&curSunit=25\# adresinden erişildi.

İstanbul Medeniyet Üniversitesi Bilgi ve Belge Yönetimi Bölümü. (2021). Tanıtım. https://bilgibelge.medeniyet. edu.tr/tr adresinden erişildi.

İstanbul Üniversitesi Bilgi ve Belge Yönetimi Bölümü. (2021a). Lisans programı. https://ebs.istanbul.edu.tr/home/ dersprogram/?id=1091\&birim=bilgi_ve_belge_yonetimi_lisans_programi_(orgun_ogretim)\&yil=2021 adresinden erişildi.

İstanbul Üniversitesi Bilgi ve Belge Yönetimi Bölümü. (2021b). Bölümün tarihçesi. https://bilgibelge-edebiyat. istanbul.edu.tr/tr/content/bolumumuz/bolumun-tarihcesi adresinden erişildi.

İstanbul Üniversitesi Bilgi ve Belge Yönetimi Bölümü. (2021c). Anabilim dallarl. https://bilgibelge-edebiyat. istanbul.edu.tr/tr/content/anabilim-dallari/anabilim-dallari adresinden erişildi.

İzmir Kâtip Çelebi Üniversitesi Bilgi ve Belge Yönetimi Bölümü. (2021). Bölümümüz hakkında. https://bby. ikcu.edu.tr/S/18484/bolumumuz-hakkinda adresinden erişildi.

İzmir Kâtip Çelebi Üniversitesi.(t.y.). Bilgi ve Belge Yönetimi Bölümü/Lisans. https://ubs.ikc.edu.tr/AIS/ OutcomeBasedLearning/Home/Index?id=432\& culture=tr-TR adresinden erişildi. 
Kastamonu Üniversitesi Bilgi ve Belge Yönetimi Bölümü. (2021). Genel bilgiler. https://fef.kastamonu.edu. tr/index.php/tr/bilgi-ve-belge-yonetimi/genel-bilgiler adresinden erişildi.

Kastamonu Üniversitesi Bilgi ve Belge Yönetimi. (t.y.). Ders içerikleri. https://fef.kastamonu.edu.tr/images/2020/ bolumler/bilgibelge/ders-icerikleri/Bilgi-ve-Belge-Yonetimi-Ders-\%CC\%B0cerikleri.pdf adresinden erişildi.

Kastamonu Üniversitesi. (2021). Ana bilim dalları. https://fef.kastamonu.edu.tr/index.php/tr/bilgi-ve-belgeyonetimi/ana-bilim-dallari adresinden erişildi.

Keskin, İ. (2003). Yakınçağ'dan günümüze Türkiye'de ve Avrupa'da arşivcilik eğitimi (Yayımlanmamış doktora tezi). İstanbul Üniversitesi Sosyal Bilimler Enstitüsü, İstanbul.

Keskin, İ. (2011). Türkiye'de arşivcilik eğitimi. G. Sarıyıldız, N. Çiçek, İ. Keskin ve S. Pamuk (Yay. haz.), Prof. Dr. Şevki Nezihi Aykut Armağanı içinde (ss. 199-216). İstanbul: Etkin Kitaplar.

Marmara Üniversitesi. (2021). Lisans programı. https://meobs.marmara.edu.tr/ProgramTanitim/fen-edebiyatfakultesi/bilgi-ve-belge-yonetimi-27-31-0 adresinden erişildi.

Odabaş, H. (2014). Atatürk Üniversitesi Bilgi ve Belge Yönetimi Bölümü öğrencilerinin bölüme ve disipline karşı tutum ve davranışları. N. Özel ve N. Er-Koçoğlu (Yay. haz.), Ankara Üniversitesi Bilgi ve Belge Yönetimi Bölümü 60. Yıl Armağan Kitabı içinde (ss. 129-142). Ankara: Ankara Üniversitesi Dil ve TarihCoğrafya Fakültesi Bilgi ve Belge Yönetimi Bölümü.

Osmaniye Korkut Ata Üniversitesi Bilgi ve Belge Yönetimi Bölümü. (2021). Bölüm güncel ders müfredatı. http://bby.osmaniye.edu.tr/42201_2021-bolum-guncel-ders-mufredat $\% \mathrm{C} 4 \% \mathrm{~B} 1 . \mathrm{html}$ adresinden erişildi.

Osmaniye Korkut Ata Üniversitesi. (t.y.). Tarihçe. http://bby.osmaniye.edu.tr/20582_tarihce.html adresinden erișildi.

Rukancı, F. (1998). Türkiye'de arşivcilik eğitimi (Yüksek lisans tezi). Yükseköğretim Kurulu Başkanlığı Ulusal Tez Merkezi. (Tez No. 72394)

Subaşıoğlu, F. (2014). Meslek eğitimimizde yeni yöntemler, firsatlar. N. Özel ve N. Er-Koçoğlu (Yay. haz.), Ankara Üniversitesi Bilgi ve Belge Yönetimi Bölümü 60. Yll Armağan Kitabı içinde (ss. 81-91). Ankara: Ankara Üniversitesi Dil ve Tarih-Coğrafya Fakültesi Bilgi ve Belge Yönetimi Bölümü.

Subaşığlu, F. ve Tamdoğan, O. G. (2014). Ankara Üniversitesi Kütüphanecilik Bölümü’ nün kuruluş öyküsü. Türk Kütüphaneciliği, 28(4), 583-621. https://dergipark.org.tr/tr/download/article-file/807973 adresinden erişildi.

Türk Dil Kurumu Eğitim Terimleri Sözlüğü. (2019). Kürsü. https://sozluk.gov.tr/ adresinden erişildi.

Yıldırım, A. ve Şimşek, H. (2018). Sosyal bilimlerde nitel araştırma yöntemleri (18. bs.). Ankara: Seçkin.

Yılmaz, B. (2018). Türkiye'de bilgi ve belge yönetimi bölümleri ders programlarının arşivcilik ve belge yönetimi eğitimi açısından değerlendirilmesi. Bilgi Yönetimi, 1(1), 44-62. https://dergipark.org.tr/tr/ download/article-file/485099 adresinden erişildi.

Yılmaz, M. (2010). Atatürk Üniversitesi Edebiyat Fakültesi Bilgi ve Belge Yönetimi Bölümü: Kuruluş aşaması ve bugünkü durumu. Türk Kütüphaneciliği, 24(1), 118-129. https://dergipark.org.tr/tr/download/articlefile/814240 adresinden erişildi.

Yükseköğretim Program Atlası. (2021). Bilgi ve Belge Yönetimi Programı bulunan tüm üniversiteler. https:// yokatlas.yok.gov.tr/lisans-bolum.php? $\mathrm{b}=10021$ adresinden erişildi.

Zhao, D., Chis, A. E., Muntean, G., Muntean, C. H. (2018). A large-scale pilot study on game-based learning and blended learning methodologies in undergraduate programming courses. Edulearn 18 Proceedings. Retrieval from: http://www.newtonproject.eu/wp-content/uploads/2018/08/4.-Zhao_EDULEARN_CameraReady.pdf 
